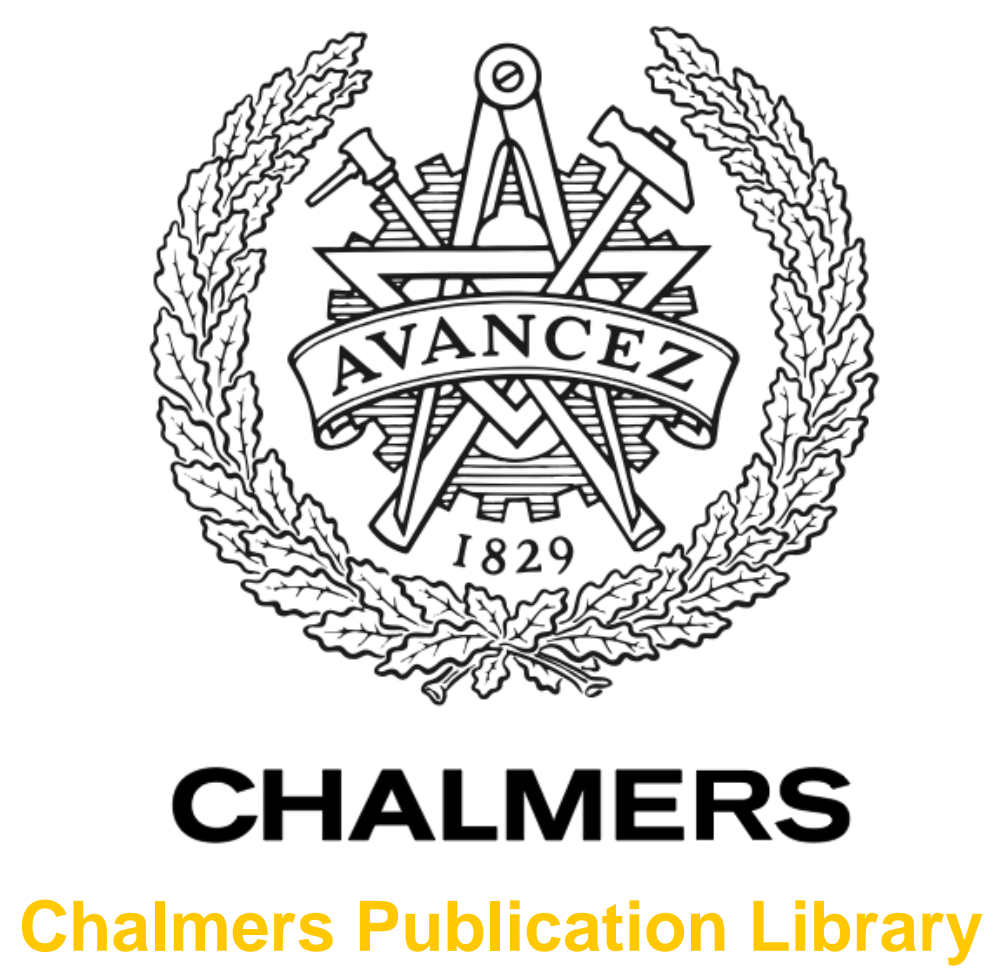

\title{
Changing from petroleum to wood-based materials: critical review of how product sustainability characteristics can be assessed and compared
}

This document has been downloaded from Chalmers Publication Library (CPL). It is the author's version of a work that was accepted for publication in:

Journal of Cleaner Production (ISSN: 0959-6526)

Citation for the published paper:

Clancy, G. ; Fröling, M. ; Svanström, M. (2013) "Changing from petroleum to wood-based materials: critical review of how product sustainability characteristics can be assessed and compared". Journal of Cleaner Production, vol. 39 pp. 372-385.

http://dx.doi.org/10.1016/j.jclepro.2012.07.027

Downloaded from: http://publications.lib.chalmers.se/publication/162827

Notice: Changes introduced as a result of publishing processes such as copy-editing and formatting may not be reflected in this document. For a definitive version of this work, please refer to the published source. Please note that access to the published version might require a subscription. 


\title{
Changing from petroleum to wood-based materials: critical review of how product sustainability characteristics can be assessed and compared
}

\author{
Gunilla Clancy ${ }^{1}$, Morgan Fröling ${ }^{2}$ and Magdalena Svanström ${ }^{1}$ \\ ${ }^{1}$ Chemical Environmental Science, Chalmers University of Technology, Göteborg, Sweden \\ ${ }^{2}$ Ecotechnology and Environmental Science, Mid Sweden University, Östersund, Sweden \\ E-mail contact: clancy@chalmers.se
}

\section{Abstract}

This paper reports on a literature survey on available approaches for the assessment of product sustainability, with a specific focus on assessing the replacement of non-renewable petroleum-based materials with renewable wood-based materials in absorbent hygiene products. The results are contrasted to needs in a specific material development project.

A diverse number of methods exist that can help in assessing different product sustainability characteristics for parts of or whole product lifecycles. None of the assessment methods found include guidelines for how to make a case-specific interpretation of sustainability and there is a general lack of assessment parameters that can describe considerations in the comparison between the use of wood or petroleum as main raw material. One reason for this is lack of knowledge and/or consensus on how to describe and assess impacts of land and water use, e.g. on ecosystem services, different types of resource depletion and social impacts.

\section{Keywords}

Non-renewable resources, Renewable resources, Sustainability assessment, Life cycle perspective, Sustainable resource management, Material development, Diaper, Nappy, Absorbent hygiene product

\section{Introduction}

Due to different concerns, such as diminishing reserves of non-renewable resources and increasing evidence of climate change related to emissions of green house gases (GHGs), many companies are shifting from non-renewable to renewable material resources, expecting that this will result in more sustainable products. However, the sustainability of products is a complex issue that depends on numerous factors; renewability and climate change are only two of these. Changing from a non-renewable to a renewable raw material does not automatically mean that the product will become more sustainable. The material 
from a renewable resource might, for instance, need more energy in the production stage, or more material might be required for the final product to fulfil its function in a satisfactory way, than if a non-renewable material resource had been used; a situation that has been discussed rather extensively in relation to biofuels, e.g. ethanol (Farrell et al., 2006; Fehrenbach et al., 2008). Therefore, in the short- to mid-term, before we actually run out of a specific fossil resource, it might in some cases be a better choice to continue to use the fossil resource until suitable materials, improved technologies, or new use patterns have been developed. In fact, it comes down to how 'sustainability' is interpreted in each specific comparison.

With increasing competition for resources following increasing global consumption, resource use needs to a greater extent be valued based on resource limitations and potential competition from other areas of use. In the case of the non-renewable resource petroleum versus the renewable resource wood as a raw material for different products, this could come down to weighing the depletion of limited petroleum resources against increasing land area requirements, including different impacts from the cultivation of wood resources and direct and indirect impacts from land use change. In any such assessment, impacts need to be related to the specific functions that are ultimately fulfilled in society by the product; therefore, a life cycle perspective is necessary, with the product's function as the point of reference. This will ensure that sustainability impacts throughout the product's entire life cycle are considered and that changes that just shift the burden from one stage to another can be avoided.

This study has been performed within the WooDi (the Wood Based Diaper) project, which aims to develop wood-based materials that can replace petroleum-based materials in the absorbent core of a diaper. The research project is a collaboration between industry and university. The goal of the project is that a diaper containing the new materials should be more sustainable than a reference diaper based on present technology. This calls for a methodology that will allow assessing and comparing the sustainability impacts associated with using these different resources in a product.

Munthe, in a report to the Swedish Agricultural Administration in 1997 (Munthe, 1997), defined three questions that should be answered before any assessment effort is started:

- What concerns should be included?

- How should potential trade-offs between the concerns be made?

- How should uncertainties in the required information be handled?

Munthe argued that these questions need to be answered in order to ensure transparency and to avoid being influenced by expected or desired results.

The same type of questions have also been highlighted by others in comparing products, e.g. by Steen in 2006 (Steen, 2006), and they are most likely useful as a basis in any product assessment. The three questions can be formulated in the following way for the WooDi project: (1) What sustainability considerations are essential to include in the product assessment, taking into account the specifics of the product systems under study and the 
challenges that emerge in light of world development and the goal of sustainable development (i.e. which assessment parameters are the most relevant to include)? (2) How should potential trade-offs between these sustainability concerns be handled if the compared sustainability profiles peak in different areas (i.e. what weighting factors should be used)? and (3) How should the yet unknown final product and product system be dealt with in a sustainability assessment?

Since the WooDi project deals with material development, many features of the final product are still unknown, at least early on in the project. Over time, more characteristics of the final product will be possible to estimate and the full product system will eventually be possible to discern. Throughout this material development process, the sustainability assessment approaches that are the most appropriate to employ will likely shift as the needs of the project change. In order to ensure that the new product is developed to become more sustainable than the reference product, the new ideas must, despite the original uncertainties, be benchmarked to a reference product that already exists on the market. The people making important choices in this process need therefore be guided through the important considerations, starting with awareness-raising exercises and working towards a quantitative to semi-quantitative comparison.

This paper reports on available literature on defining, assessing and comparing the sustainability of products made from renewable (wood-based) respectively non-renewable (petroleum-based) materials, specifically for products or activities that are of relevance for the WooDi project, i.e. absorbent materials in diapers and other hygiene products. Knowledge and methodology gaps that need to be filled in order for a sustainability comparison to be performed within the WooDi project are discussed.

\section{Research method}

In order to provide information to the WooDi project, which aims at achieving a shift from petroleum to wood as the material base for the absorbent core of an incontinence diaper, a literature survey was carried out on available sustainability impact assessment approaches. Besides creating an overview of existing assessment approaches that could prove useful in the project, an emphasis was put on exploring which assessment parameters that have been in actual use in assessing materials of fossil and biological origin and how these parameters have been selected, in order to provide input to the comparative assessment that is to be conducted within the WooDi project. By contrasting the results from the survey with the needs of the WooDi project, existing gaps in knowledge and methodology were evaluated and further steps that need to be taken were identified.

Regarding approaches and techniques for the assessment of environmental sustainability from a systems perspective, an overview has been published earlier by other authors (CHAINET, 2002). In the present paper, the investigation was narrowed down to what is most urgently needed in the WooDi project, i.e. the state-of-the-art in terms of comparing 
the sustainability characteristics of products made from petroleum-based and wood-based materials.

Figure 1 provides an overview of the ideas underlying the present study and the type of results that will be reported on in this paper. Different approaches found in literature have been classified according to the CHAINET nomenclature regarding assessment approaches for the environmental dimension of sustainable development (CHAINET, 2002; Wrisberg et al., 2002); 'analytical approaches' are mainly employed to assess the impact of a product system, while 'procedural approaches' primarily focus on determining whether certain requirements are fulfilled.

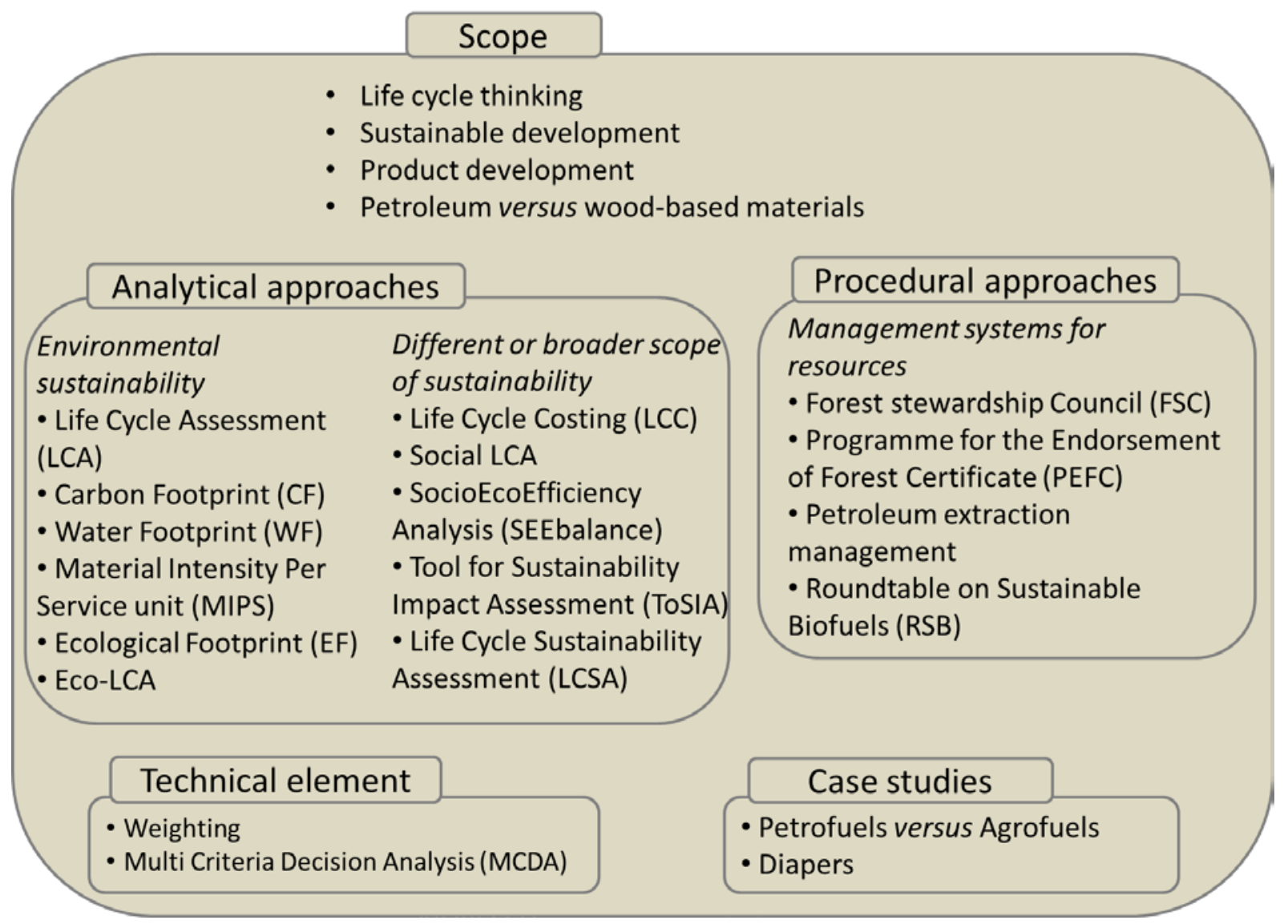

Figure 1. An overview of approaches and techniques discussed in this paper.

In Figure 1, the 'scope' summarises underlying theories and delimitations of this study, as discussed in the previous section. In Section 3, analytical approaches that assess the life cycle performance of products based on one or several environmental parameters are reviewed, including issues related to weighting and also some analytical approaches with a broader, more holistic, scope. In Section 4, procedural approaches such as certification schemes for different resources and biofuels are reviewed. These often include assessment parameters important for resource extraction or cultivation stages which are normally not considered in e.g. life cycle assessments due to the difficulty in measuring things like biodiversity and social progress. In Section 5, case studies, in which products with 
petroleum and biomass-based materials are compared and reviewed along with case studies assessing diapers. Finally, in Section 6, an overview of sustainability assessment parameters and their use is given and how the different analytical and procedural approaches can be used in the WooDi project is discussed. Only approaches and results relevant to the WooDi project are reported on, i.e. they deal with the sustainability assessment of products and resources and provide input to making a comparison of the use of petroleum and wood-based materials.

\section{Analytical approaches for assessing the life cycle performance of products}

\subsection{Environmental performance}

Life Cycle Assessment (LCA) methodology is widely used to evaluate the environmental performance of product systems. An LCA studies potential environmental impacts of a product or service throughout its life, from resource acquisition through production, use and waste management, by mapping and evaluating flows crossing the system boundary, see for example Pennington et al. and Rebitzer et al. for a more thorough description of LCA methodology (Pennington et al., 2004; Rebitzer et al., 2004). LCA is a standardised method for the environmental assessment of products, included in the ISO 14040 series. An LCA should include the whole life cycle and should look at as many environmental impacts (ecological consequences, resource use and impacts on human health) as necessary to comprehensively reflect the goal and scope of the study. In most cases, only a few selected impact categories and a limited part of the total life cycle are considered. The goal and scope definition is extremely important since the LCA will mainly answer the questions it is designed to answer. Given that different LCAs have different objectives, it is often impossible to directly compare their results. LCA approaches that focus on a specific impact category are for example the Carbon Footprint (CF), the Water footprint (WF) and the Material Input Per Service unit (MIPS).

Depending on the scope of the LCA, different modeling approaches can be utilized, and this can strongly influence the results, for example if the study is attributional or consequential, and how and to what extent system expansion has been used (Earles and Halog, 2011). The system expansion methodology can add substantially to the understanding of potential consequences of a proposed change, but at the same time, the system model will be even more complex and often more difficult to grasp. For bio-based materials, a relevant example is for land use. In an attributional study, the land that is needed for the biomass production will be included together with any direct environmental impacts from using the land. In a consequential study also indirect land use changes will be included, e.g. when displaced activities lead to land use change in other areas (Earles and Halog, 2011). It has been suggested that scenario modeling could support a consequential 
study in providing a more complete description of the potential consequences (Zamagni et al., 2012).

\subsubsection{Assessment of specific impact categories}

For comparisons between products based on renewable and non-renewable resources, there are some potentially relevant impact categories that have received special attention.

The Carbon Footprint (CF) is a concept that has gained interest in recent years, with the increased public concern for climate change (Wiedmann and Minx, 2007). The CF reports on the overall amount of carbon dioxide emissions and in more rigorous studies also other GHG emissions (e.g. methane and nitrous oxide), associated with a product. Basically, it is an LCA that focuses solely on carbon dioxide or on GHGs. Disparities in the definition of this rather commonly used concept have led to standardisation efforts, resulting in the British standard PAS 2050 (PAS 2050, 2008). Besides the GHG emissions from technical activities during a life cycle, this standard includes how to calculate emissions from direct land use change due to increased use of biomass resources. Direct land use change refers, for example, to the conversion of non-agricultural land to agricultural land as a consequence of increased production of agricultural products, which typically deteriorates the carbon storage capacity of the soil. This is of great importance, e.g. for biofuel production chains; failing to consider this might overestimate climate benefits (Bringezu et al., 2009b; Börjesson and Tufvesson, 2011). If the biological feedstock is instead produced on degraded soil, with low original carbon storage capacity, it can potentially contribute to an improvement of the soil carbon storage capacity. The impact of indirect land use change, i.e. land use change induced in other areas is, however, not yet included in PAS 2050. This is due to the lack of data; otherwise very few CF analyses would be able to comply with the standard. Efforts to account for indirect land use change can be found in the literature (Cornelissen and Dehue, 2009; Gnansounou et al., 2008b; Searchinger et al., 2008). It is likely that the new materials developed within the WooDi project will lead to an increase in the use of forest biomass for incontinence protection and both direct and indirect land use changes could be relevant to assess.

Awareness of that fresh water is a limited global resource has increased in recent years, resulting in the concept of Water Footprint (WF). A product's WF is defined as the total volume of fresh water used, directly or indirectly, to produce the product (Hoekstra et al., 2009; Water Footprint Network). The WF of a product is divided into green, blue and grey water, where green water refers to rainwater stored in the soil as soil moisture, used for plant growth, blue water refers to surface and ground water for technical use in processes or for irrigation, and grey water refers to polluted water and is defined as the volume of freshwater needed to dilute the water to pollutant levels required by existing water quality standards (Hoekstra et al., 2009). There are ongoing efforts to establish practises for how to include water use in established LCA procedures, e.g. the WUCLA project within the UNEP/SETAC Life Cycle Initiative (Kounina et al., 201X). In WooDi, the production of wood-based materials is assumed to take place in the Nordic countries. Water is normally 
not seen as a scarce resource in the Nordic countries, however, a small water footprint could still be useful or even important when promoting the product in other countries. Water pollution relating to both petroleum and wood acquisition as well as to different production processes, might be important to include in the WooDi project and the categories in the WF could prove useful as assessment parameters.

Material Input Per Service unit (MIPS) is a material flow accounting method with products or services as study objects (Ritthoff et al., 2002). Impacts throughout the whole life cycle are considered, however, MIPS focuses only on the input side. The argument is that all material input will eventually become an output, e.g. waste or emission. Therefore, by measuring the input, one can arrive at an estimate of the potential environmental impact. MIPS calculates the use of resources from the point of their extraction from nature, i.e. the tonnes of moved renewable raw materials, non-renewable raw materials, water or air. All material consumption should be traced back to primary resource consumption. MIPS is unspecific to particular materials and therefore does not include substance-specific hazards. For the WooDi project, MIPS might be a method for early screening of the amount of renewable and non-renewable resources used for the different diapers as well as one of the assessment parameters in the final sustainability assessment, however, it has to be complemented with parameters that can provide greater level of detail of the potential impacts of the input flows and also of the output flows.

Biomass resource use has impacts on land resources, for example as occupied land area or changes in soil quality. Since biomass resource use might increase if diapers, to a larger extent, are produced from wood resources, this should be considered in the WooDi sustainability assessment. In an LCA, the fact that land area is a limited resource is generally not taken into account. If included, it is usually as land area occupation. The ecological footprint (EF) is a related concept that includes not only the occupied land but also involves a recalculation of other environmental impacts into potential land area occupation. This concept will therefore be discussed further also in Section 3.1.2 as a weighting method in LCA. Regarding land area, Helming et al. argue that even though land cannot be depleted from a spatial point of view, the possibility for different types of use of the land can be changed or depleted, hence land quality can be depleted (Helming et al., 2008). The manner in which land is used, often referred to as land use (IPCC, 2000), is a parameter that is rarely included in LCA studies, but the inclusion of impacts from land use into LCA has been proposed by several researchers (Antón et al., 2007; Mattsson et al., 1998; Mendoza and Martins, 2006; Michelsen, 2008; Swan, 1998; Vogtländer et al., 2004). In agricultural production, land use can be considered a very significant impact category due to its potential influence on soil quality and it has been applied in some studies of agricultural products (Mattsson et al., 2000). Biodiversity is one area that is strongly affected by land use, e.g. by loss, modification and fragmentation of habitats and the degradation of soil and water (Foley et al., 2005; MEA, 2005). To include biodiversity as an assessment parameter in LCA has been proposed, e.g. by Penman et al. (Penman et al., 2010), identifying the lack of a common definition of biodiversity as a main reason for the absence of measurable indicators. In order to include considerations of biodiversity in EF, a land area for 
biodiversity protection can be set aside, for example the $12 \%$ used in the original EF methodology presentation (Wackernagel and Yount, 1998) that was based on the Brundtland commission recommendations in 1987 in the report Our Common Future (WCED, 1987). The authors stated, however, that $12 \%$ might not be sufficient but they used it as a politically achievable share. A more recent UN-hosted initiative from 2009, intended to draw attention to the global economic benefits of biodiversity, suggests that a minimum of $15 \%$ of global land areas should be protected (TEEB, 2009). Berndes et al. conclude that how the use of land interacts with biodiversity, soil quality and global food, material and energy production needs to be defined and parameterised (Berndes et al., 2003). A proposed life cycle oriented approach that might be able to handle such issues is Eco-LCA (Baral et al., 2012; Zhang et al., 2010). Eco-LCA includes emergy analysis in describing consumption of natural resources such as ecosystem goods and services including biodiversity.

One difficulty with the land use aspect is thus that in order to provide meaning, it needs to be further parameterised into quantifiable entities regarding e.g. soil quality, biotic production potential and biodiversity. These impacts often interact with each other and how to quantify them in relevant ways will likely also vary with geographical conditions, which makes the evaluation complex (Milà i Canals et al., 2007); a lot of local data would be needed for the appropriate inclusion of land use in LCA. An LCA study that utilised detailed and site-specific land use inventories in a study of three vegetable oil crops highlighted erosion, soil organic matter, soil structure, soil $\mathrm{pH}$, soil $\mathrm{P}$ and $\mathrm{K}$ status and impacts on biodiversity as important land use aspects (Mattsson et al., 2000). A recent review of developments in LCA stresses the need for further development on the impact assessment of land use (Finnveden et al., 2009). In assessing the sustainability impacts of the WooDi materials, land use and biodiversity issues should be addressed, but there is presently a lack of ready-to-use methods for doing so.

\subsubsection{Weighting}

In comparisons of the performance of two products, unless one product performs better than the other one for all selected assessment parameters, there is a need for the aggregation of results into a more holistic measure. There are several different weighting methods for environmentally related impacts with set weighting factors, commonly used in the LCA society. Some examples are Ecoscarcity 97, EDIP, Ecoindicator 99 and EPS2000 (Baumann and Tillman, 2004). Different methods are based on different value-systems and may provide different answers to which development routes are preferable. Finnveden concluded in 1999 that there is no single available pre-made method with set weighting factors that can be recommended, because they all suffer from different issues like significant data gaps, inconsistencies, or lack of justification of important assumptions (Finnveden, 1999). However, the use of weighting can still provide a greater understanding of LCA results (Bengtsson and Steen, 2000). 
Several weighting methods available in literature include resource use in different ways. One example is the monetary values used by the Environmental Priority Strategies (EPS) method (Steen, 1999). Monetary values reflect the willingness to pay to safeguard the subjects human health, biological diversity, ecosystem production capacity, abiotic resources, and cultural and recreational values. The impact category for abiotic resources is the depletion of abiotic reserves; weighting factors for non-renewable resources are based on the cost of producing an equivalent amount from renewable resources and for renewable resources, weighting factors are based on their market price.

Other weighting methods like CML 2000, ReCiPe and IMPACT 2002 include nonrenewable resources based on the 'resource to use' characterisation, where different resources are related to each other based on the ratio of the present speed of consumption over presently known reserves (European Commission, 2009a).

The EF methodology, estimating the biologically productive area needed to support current consumption patterns (Holmberg et al., 1999; Wackernagel and Rees, 1996), has generally been used for analysis of the impact of the consumption in nations and regions but can also be used as a weighting method in LCA (Wackernagel and Yount, 2000). The EF is calculated by translating all impacts from material and energy consumption and other activities, and land occupation, of, e.g. a product, a household, a local community, a region, or the whole of mankind, into area demand (measured in hectares). For example, a city not only occupies the actual ground that is covered by buildings and infrastructure; it also needs agricultural land, e.g. for food and fibre, sea area, e.g. for fishing, forest, e.g. to produce wood-based products and to assimilate $\mathrm{CO}_{2}$ released from the combustion of petroleum fuels, and so forth. Thus, besides the area directly occupied, the material and energy use, and the generation of emissions and waste, have to be compiled and recalculated into an EF area, generally by multiplying by a land need index (Wackernagel and Yount, 1998). Such indices are calculated using LCA methodology. The EF thus recalculates resource use into area use, but it only considers renewable resource consumption. Including the consumption of non-renewable resources as an abiotic area use has been proposed (Nguyen and Yamamoto, 2007). The suggested approach includes resource depletion for metals but not for petroleum.

Some other methods do not include resource use, but instead rely on the assumption that the resource issue will be solved by the market, i.e. the price will depend on the availability of and the demand for the resource and therefore it does not need to be considered in the environmental assessment (Udo de Haes et al., 2002). In those cases, resource depletion is not seen as an environmental impact but rather as a social or economic one and is therefore omitted.

When it comes to product development for sustainable development, a method is needed that can guide in choosing resources that will not face severe restrictions exhibited by limitations on nature or society in the future, where resource use and resource availability will be different from today. There are many different methods and prototypes in diverse niche areas for assessing future products' or materials' life cycles or parts of life cycles 
(Finnveden and Moberg, 2005; Höjer et al., 2008; Robèrt, 2000), but case studies in which they have been applied are rare.

It is generally recognised that the valuation element involved in weighting has to be based on political, ideological and/or ethical values and that these are influenced by people's perceptions and worldviews. Not only the individual weighting factors used in a specific method, but also the choice of valuation methodology and even the choice to use a weighting method at all, are influenced by fundamental ethical and ideological values (Finnveden, 1997).

Weighting can be made based on the opinions of participants in a weighting process, often with the major purpose of providing more structure and transparency to decision-making. It also offers the opportunity to introduce qualitative data and data outside of the environmental area. Multi Criteria Decision Analysis (MCDA) is such an approach (Mendoza and Martins, 2006). MCDA can be used in multi-stakeholder discussions within a company or project to derive at weighting sets and to illustrate the effects of different weighting sets.

In the WooDi project, the application of different weighting methods along with different scenarios for the future can introduce different value-systems and a way to deal with uncertainties about future world and product system development, and thereby provide a more comprehensive understanding of the implications of the assessment results. The weighting methods described above mainly deal with the environmental area and cannot account for the broad range of sustainability parameters that will have to be dealt with in the project, however, they can provide partial understanding of the potential impact. EF, for example, might be relevant to use for initial screening and as an assessment parameter in the final sustainability assessment, especially if the depletion of non-renewable resources can be integrated. To introduce also qualitative parameters and other parameters than environmental ones, MCDA can be useful. When used as a group process, it can also clarify the trade-offs and the implications of gaps in information and knowledge to the participants.

\subsection{A different or broader scope of sustainability}

Life Cycle Costing (LCC) is a method developed for assessing internal and external costs related to a product over its entire life cycle (Woodward, 1997). Internal costs are company costs, e.g. for research, development, planning, assets and operation and external costs are related to, e.g. environmental impacts and social effects that today are costs for society (Rebitzer and Hunkeler, 2003). An argument, other than social responsibility, for the assessment of external costs is that they tend to become more and more internalised over time as the awareness of impacts related to company activities increases, as has been the case for, e.g. today's environmental policy instruments regarding emissions, like carbon trading. Any future-oriented assessment needs to anticipate potential upcoming costs or impacts. In a review of the ways in which goal and scope are defined in LCC, it was found that most LCC studies cover only a few parts of the whole life cycle and most often at a low level of detail, i.e. a very limited type of future costs, like running costs and final waste 
handling or demolition costs and rarely external costs (Korpi and Ala-Risku, 2008). LCC could be useful in the WooDi project for comparing investments needed for alternative solutions in material production and to gain a greater understanding of how product cost is influenced by different impacts. The scope of the LCC could be enlarged and/or could include more details as the project proceeds and more information on the product system appears.

Social LCA is in an early stage of development compared to environmental LCA (Hunkeler, 2006; Kloepffer, 2008). Case studies are needed in order to develop the method further (Benoît et al.). A review of Social LCA studies concluded that they rely on somewhat different approaches, e.g. use either generic or site specific data and include different sets of impacts, ranging from direct impacts on workers only, like rates of injury, to broader societal consequences such as general support to developing countries (Jørgensen et al., 2008). UNEP has published a report presenting a framework for the assessment of product life cycle social impacts (Andrews et al., 2009). In this framework, social impacts are consequences of positive or negative pressures on human well-beings from an organisation's activities. The UNEP framework divides social impacts into three areas, based on what causes them: (1) social impacts caused by a specific behaviour or decision, e.g. forbidding employees to form unions or allowing child labour, (2) social impacts effected by socio-economic decisions, e.g. an investment decision to build infrastructure in a community and (3) social impacts related to human and cultural capitals, e.g. activities to improve education or health level (Andrews et al., 2009). Similar to environmental LCA, Social LCA needs a considerable amount of data input. As presently used, Social LCA mainly gathers information on organisational aspects at the enterprise or management level throughout product life cycles. In product or material development, things like location of production facilities, production volumes and customer response are often yet unknown and thereby data for several social impacts are unavailable. Social LCA, as of today, is more useful in later stages of product development when there is more information available about the product system. However, it is an advantage to be aware of what it includes throughout the whole development process so that development can be guided.

Life Cycle Sustainability Assessment (LCSA) has been suggested by e.g. CALCAS (Zamagni et al., 2009) and the UNEP/SETAC life cycle initiative (Ciroth et al., 2011) to broaden the scope of current LCA by for example combining environmental LCA, LCC and Social LCA into an integrated assessment covering the three dimensions of sustainability. Case studies are needed to develop the LCSA methodology.

SocioEcoEfficiency Analysis (SEEbalance) sets out to compare the sustainability of products and processes from a holistic perspective (Kölsch et al., 2008; Saling et al., 2005; Schmidt et al., 2004). It is a further development of the Eco-efficiency analysis, and it is developed and used by the chemicals producer BASF (Saling et al., 2002). SEEbalance includes, in addition to life cycle costs and life cycle environmental impacts, also social effects. The exact choice of sustainability indicators has a considerable effect on the result, hence results from different studies can normally not be directly compared (Lindner et al., 2010). Table 1 lists examples of sustainability indicators used in the SEEbalance method. Note that the social 
indicators are both positive and negative, whereas commonly used environmental impacts are negative (a higher value would indicate a higher negative impact). The developers of the SEEbalance methodology argue that a generally applicable set of indicators should be strived for to facilitate the creation of databases. However, they claim that no standard set of social indicators can be set up for the use stage of the product's life cycle since this depends on the product's specific purpose, whereas the indicators for resource acquisition, production, manufacturing and waste management can be the same for all products (Schmidt et al., 2004). It is thus necessary to consider the effects of the use stage case by case, in other words, the analyst needs to compile suitable assessment criteria and a relevant way to quantify them. Results of investigated social indicators are eventually aggregated based on two types of weighting factors: (1) the 'relevance weighting factors' which are evaluated for each analysis and reflect the examined product's influence on social issues on a national level and (2) the 'societal weighting factors' which are the same for all analyses carried out in the same country within a comparable time period and express a subjective assessment based on, e.g. public opinion polling and expert interviews on the general importance of the different social issues with regard to sustainable development (Saling et al., 2002). The same approach is used for environmental and economic indicators. The aggregated environmental, economic and social indicators for each studied alternative are normalised in relation to the least favourable result for the indicator that is set to one, and plotted in a so called SEEcube with environmental impact, costs and social impact on the three axes. Because of the uncertainties involved in the analysis, a large difference between studied alternatives is needed to obtain a significant result.

To our knowledge, no case studies are available in open literature in which SEEbalance has been used and therefore, it is not possible to review how products based on petroleum oil and wood biomass have been compared.

Table 1. Sustainability indicators suggested for SEEbalance analyses (Saling et al., 2002; Schmidt et al., 2004) and for ToSIA (Lindner et al., 2008; Lindner et al., 2010). The text has been shortened in some cases; see references for full lists.

\begin{tabular}{|c|c|c|}
\hline $\begin{array}{l}\text { SEEbalance environmental } \\
\text { indicators }\end{array}$ & $\begin{array}{l}\text { SEEbalance economic } \\
\text { indicators }\end{array}$ & SEEbalance social indicators \\
\hline 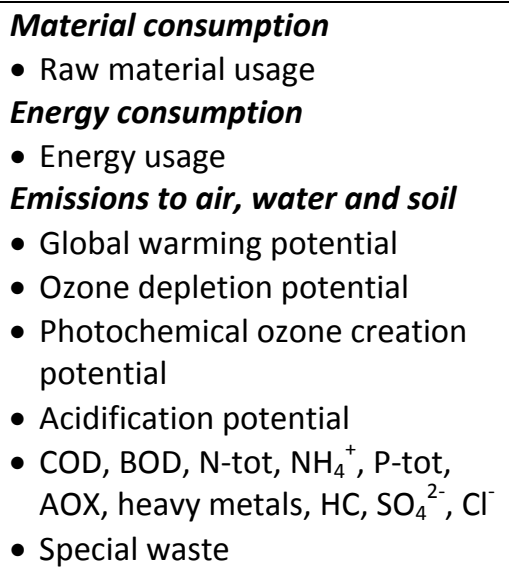 & $\begin{array}{l}\text { Total costs } \\
\text { - Sales price }\end{array}$ & $\begin{array}{l}\text { Employees } \\
\text { - Occupational and commuting accidents } \\
\text { - Occupational diseases } \\
\text { - Wages and salaries } \\
\text { - Company benefits such as subsidies } \\
\text { - Expenditures for professional training } \\
\text { - Strikes and lockouts } \\
\text { Suppliers/business partners } \\
\text { - Freedom of association } \\
\text { - Discrimination } \\
\text { - Forced labour } \\
\text { - Child labour } \\
\text { End customers/consumers }\end{array}$ \\
\hline
\end{tabular}




\begin{tabular}{|c|c|c|}
\hline $\begin{array}{l}\text { SEEbalance environmental } \\
\text { indicators }\end{array}$ & $\begin{array}{l}\text { SEEbalance economic } \\
\text { indicators }\end{array}$ & SEEbalance social indicators \\
\hline $\begin{array}{l}\text { - House waste } \\
\text { - Building rubble } \\
\text { Toxicity potential } \\
\text { - } \mathrm{LD}_{50} \\
\text { Risk potential } \\
\text { - Workplace accidents } \\
\text { - Transportation accidents } \\
\text { - Abuse risks } \\
\text { - Plant safety } \\
\text { - Fire behaviour } \\
\text { - Land use } \\
\text { - Noise } \\
\text { - Quality defects }\end{array}$ & & $\begin{array}{l}\text { - Toxicity potential } \\
\text { - Additional health risks (e.g. danger of accidents, } \\
\text { - Extra benefits that enhance customer satisfaction } \\
\text { - Completeness and quality of product information } \\
\text { - Consumer labels (e.g. 'EU flower') } \\
\text { Neighbourhood and society } \\
\text { - Number of employees; unskilled workers; female } \\
\text { - } \text { - Companagers; disabled employees; part-time workers } \\
\text { - Benefits for disadvantaged people due to product } \\
\text { quality } \\
\text { - Violation of ethical norms due to product use or } \\
\text { advertisement } \\
\text { - Potential of misuse of products (e.g. as a weapon) } \\
\text { - Potential of intensification of social and political } \\
\text { conflicts (e.g. due to changes of traditional } \\
\text { lifestyles) } \\
\text { Future generations } \\
\text { - Expenditures for R\&D } \\
\text { - Capital investment } \\
\text { - Company expenditures for social security } \\
\text { - Number of trainees } \\
\text { International community } \\
\text { - Imports from developing countries } \\
\text { - Sum of import duties and export subsidies } \\
\text { (protectionism) } \\
\end{array}$ \\
\hline ToSIA environmental indicators & ToSIA economic indicators & ToSIA social indicators \\
\hline $\begin{array}{l}\text { Total energy generation and use } \\
\text { - Renewable } \\
\text { - Non-renewable } \\
\text { - Electricity from the grid } \\
\text { GHG emissions \& carbon stocks } \\
\text { Generation of waste } \\
\text { Water use } \\
\text { Soil, water and air pollution } \\
\text { Transport distance and freight } \\
\text { Forest biodiversity } \\
\text { Forest resources use }\end{array}$ & $\begin{array}{l}\text { Gross value added } \\
\text { Productivity } \\
\text { Investment and R\&D } \\
\text { Total production costs } \\
\text { - Raw materials from } \\
\text { forest wood chains } \\
\text { - Raw material from } \\
\text { outside forest wood } \\
\text { chains } \\
\text { - Labour costs } \\
\text { Energy costs }\end{array}$ & $\begin{array}{l}\text { Total employment } \\
\text { - Male } \\
\text { - Female } \\
\text { Total wages and salaries } \\
\text { - Male } \\
\text { - Female } \\
\text { Occupational safety and health } \\
\text { - Non-fatal accidents } \\
\text { Education and training }\end{array}$ \\
\hline
\end{tabular}

The sustainability assessment in the WooDi project aims to provide an answer to if the new diaper with wood-based absorbent material is more sustainable than today's containing a petroleum-based absorbent material. SEEbalance aims for comparing the sustainability of two products and could be used in comparing the final WooDi product to the reference product. However, it is less useful during the WooDi product development stage when a lot of features of the product system are unknown. The SEEbalance indication of relative improvements can be used as one measure of more sustainable products (Dyllick and Hockerts, 2002). In product development, an understanding of the sustainability 
implications of different choices that can be made for a product system is needed, which allows for rethinking the system and innovating towards a more sustainable product. The SEEbalance tool does not presently provide any guidance on e.g. how to select parameters and how to think about the future.

The assessment method and software Tool for Sustainability Impact Assessment (ToSIA) was developed within the EU financed project Eforwood, specifically for sustainability impact assessment of European forestry wood chains (Eforwood, 2009; Lindner et al., 2010; Lindner et al., 2012). An example of a forestry wood chain is: stand generation, harvesting, transport, pulping, paper-making and printing. The ToSIA tool is designed to answer 'What if' questions regarding impacts on sustainable development from the European forestry wood chains. Some examples of such questions are: "How will the impact of a specific forestry wood chain on sustainable development change if the price of petroleum oil doubles?" or "...if new policies for habitat protection are introduced?". The end of Table 1 presents sustainability indicators and some sub-indicators included in the ToSIA software, as reported by Lindner et al. (Lindner et al., 2008; Lindner et al., 2010).

If needed, additional indicators can be defined and introduced into the ToSIA software. A cost-benefit analysis tool, in which all indicators' values are converted into Euros and a certain multi-criteria analysis (MCA) procedure, are available in ToSIA. In the MCA procedure proposed, a panel of stakeholders can suggest weighting factors as indicators and rank alternatives to illustrate the effect on the results of applying different valuesystems.

The ToSIA methodology can be used both in the sustainability assessment of products and in comparisons of products. It is currently not possible in ToSIA to compare a wood-based value chain with a competing material chain, e.g. one based on petroleum. However, it would be possible to expand and develop further the methodology for other resource value chains. Sets of indicators developed for ToSIA could be helpful as input in developing caserelevant assessment parameters for the WooDi project. The cost-benefit analysis and MCA tools in ToSIA can be useful in aggregating and interpreting results from assessments within WooDi. ToSIA case studies have been reported, assessing for example forest management, harvesting, logging and transport processes in forest wood chains in European countries (Berg et al., 2012; Chesneau et al., 2012; Wolfslehner et al., 2012). Interesting specifics for forest management practices are described, but these are not of direct use for the purpose of this study.

\section{Procedural approaches for assessing resource management}

\subsection{Forestry}

Increased use of biological resources will likely lead to impacts on e.g. biodiversity and cultural values of land. There are systems, to be used by forest owners, that guide towards more sustainable forest management, e.g. the Forest Stewardship Council (FSC) 
certification (Forest Stewardship Council, 1996) and the Programme for the Endorsement of Forest Certification (PEFC) scheme (PEFC, 2010). Requirements within such systems include a broad set of aspects aimed at the sustainable management of forest resources. However, they do not take into consideration how the resources are later used in different products. These systems generally are on/off systems - you either fulfil the requirements of the system or you do not - and are thus not directly comparable to approaches like LCA or EF that, in contrast, give better/worse results on a continuous scale. The scope of this kind of system can be understood by looking for instance at the eight sustainability indicator categories suggested by the Sustainable Forest Management Laboratory (SFM, 2009): Conservation of biological diversity, Maintenance of productive capacity of forest ecosystems, Maintenance of ecosystem health and vitality, Conservation and maintenance of soil and water resources, Maintenance of forest contribution to global carbon cycles, Maintenance and enhancement of socio-economic benefits, Cultural, social and spiritual needs and values and Legal, institutional and economic framework.

FSC certification was introduced in 1993. An investigation of its progress concludes that the original intention to save tropical biodiversity through certification has failed and most certified areas are in Europe and only 10\% are located in tropical countries (Rametsteiner and Simula, 2003). The certification has been very successful, however, in raising awareness and knowledge levels regarding sustainable forest management. As continuous improvement is built in to the certification system, forest management is continuously improved in each certified area. The management systems do not, however, guarantee sustainable forest management, but work in the direction of more sustainable forest management.

FSC certification and PEFC are both international systems and both systems allow for some adaptation to national conditions in consultation with different stakeholders. This is carried out differently in the two systems; FSC is centralised and based on international indicators while PEFC is decentralised and based on regional guidelines. This means that FSC is more similar around the world than PEFC. On the other hand, PEFC is, due to its regional adaptation, more flexible and can address local issues, like particular plants and animals due to special geographical conditions. FSC certification is adapted to national and subnational indicators in each country via negotiations with different stakeholders like state agencies, forest owners, non-governmental organisations and different types of local communities. FSC certifications can therefore take into consideration national matters such as specific laws or native people's cultures. However, even though forests are highly diverse around the globe, FSC certifications do not include considerations of variations in local geographical conditions. PEFC also applies a multi-stakeholder approach and therefore varies between regions, sometimes also within counties; PEFC criteria are, for example, different for the north and the south of Sweden. Since both FSC and PEFC take into account the different interests of several stakeholders, trade-offs between different interests are necessary. Originally the PEFC system had its main focus on small-scale forestry owners while the FSC system focused on large-scale owners, but today it is possible to hold an FSC/PEFC dual certification. 
For both FSC certification and PEFC in Sweden, at least 5\% of the land area used for forestry should be set aside for biodiversity protection. In practice, this generally translates into the $12 \%$ earlier discussed, regarding EF and the Brundtland commission recommendation, after the addition of other land that should be set aside, according to the certification schemes, such as border zones alongside roads and lakes to avoid erosion and to secure water quality when harvesting. Neither of the certification schemes have systems for handling local variations potentially of great importance for biodiversity on a local level, like snags of different species and the number of windfalls that should be left.

It has been suggested that aesthetic values should be included in the assessment of the utilisation of forest resources (Panagopoulos, 2009). This would require new forest management standards and a way to estimate the public opinion of forest aesthetic values.

For the WooDi project, the share of the forest area that is certified by FSC and/or PEFC could be used as an assessment parameter indicating an acceptable level of resource management, including, e.g. responsibility for biodiversity, at least until more detailed indicators can be developed.

\subsection{Petroleum oil extraction}

Regarding petroleum oil extraction, no sustainable management systems comparable to the forest management systems have been found. There are some recommendations from the Energy and Biodiversity Initiative, consisting of leading conservation organisations and energy companies, that point to issues similar to those in the forest management systems, e.g. to include the conservation of biodiversity in strategies for petroleum and gas exploration and processing (EBI, 2003). As for all other sectors, there are Quality Management Systems, such as the ISO 9001:2008, that can be applied to petroleum oil extraction. There are also different technical standards for certain activities and products and fuel standards (ASTM, 2009), but no standard with the main aim of resulting in longterm sustainable petroleum extraction and management.

\subsection{Biofuels}

Biofuels are not of direct interest in the WooDi project since what is studied is a woodbased material that is to be used in the absorbent core of an incontinence diaper. However, management systems for other products that are bio-based and that compete with nonrenewable materials might provide valuable information on important considerations in the comparison, especially if they include an attempt to compare the use of wood and petroleum.

With the increasing interest in biofuels, certification schemes have been discussed. In 2006, Smeets et al. suggested a certification system for sustainable ethanol production, recommending that e.g. soil quality, erosion prevention, biodiversity preservation, reforestation, local food security and land use competition should be considered (Smeets et al., 2006). The Roundtable on Sustainable Biofuels (RSB) is an international initiative 
involving farmers, companies, non-governmental organisations, experts, governments and inter-governmental agencies. In 2008, the RSB released its first draft of a generic standard for sustainable biofuels production (RSB, 2008). The RSB standard includes requirements for areas similar to the criteria suggested by Smeets et al. The draft is a starting point for greater awareness and enables a move towards more sustainable production and was not developed to compare biofuels but rather to give credibility to the biofuel producer.

In 2008, an analysis was presented of 20 different certification systems for biofuels from agricultural and forestry products. In the study, Fehrenbach and co-workers concluded that environmental indicators like energy balance, GHG emissions in the biofuel production chain and waste management were only rarely dealt with and that competition for land area, food safety and usage of the products were not addressed at all in any of the 20 certification systems (Fehrenbach et al., 2008). A number of the aspects that where included, like the conservation of biodiversity, still lacked measurable indicators. The UNEP Resource Panel reports similarly on the global situation of assessing biofuels, and also highlights the importance of including not only global warming but also eutrophication and acidification in comparative assessments of biofuels from energy crops and fossil fuels (Bringezu et al., 2009a). A similar conclusion, that generally very few environmental impacts are actually assessed, is also reported in a review of 47 life cycle based studies comparing bio-ethanol systems to conventional fuel; generally only GHGs and net energy were considered (von Blottnitz and Curran, 2007).

A review of accounting approaches for quantifying GHG emissions relating to direct land use change and indirect land use change from biomass has been reported (Fritsche et al., 2010). The review focuses on discussions on options for reducing indirect land use change and recommendations for inclusion of land use change in bioenergy and biofuel policies. The EU directive on renewable energy of 2009 includes guidelines for how to calculate impacts of GHG emissions of biofuels and points out biodiversity as an important factor to consider (European Commission, 2009b).

In terms of biodiversity protection, a risk minimisation strategy in biomass use has been suggested in a strategy for certification of biomass in international trade (U. R. Fritsche et al., 2010). The strategy addresses three core issues 1) Conservation of land with a significant biodiversity value, 2) Minimizing negative effects from indirect land use change and 3) Agricultural practices with low negative effects on biodiversity.

In a study of ranking sustainability criteria for bioenergy systems, experts expressed a concern on the lack of holistic view in the sustainability assessment framework i.e. a lack of understanding of how the parameters together build a relevant parameter set that answers the question at hand (Buchholz et al., 2009). To create such a holistic overview, Buchholz suggested using participatory exercises, i.e. including various stakeholders' voices and values, such as the earlier described MCDA method, since that has proven useful on complex issues in fields related to bioenergy. 
For the WooDi project, the described systems provide examples of areas to include and indicators and methods that can be applied, however, the lack of measurable indicators within some important areas will have to be dealt with.

\section{Case studies - comparisons of products derived from petroleum and biomass}

\subsection{Agrofuel and petrofuel}

A large part of the scientific discussion on fossil versus biological resources has, so far, been focused on future fuels for transportation. There is vast literature on assessment of agrofuels and other first-generation biofuels, including comparisons with petrofuels. Most such studies have focused on the assessment of GHG emissions, often referred to as the CF. Examples of recent such studies have been reported by Edwards et al. in 2007, by Johnson and Heinen in 2008 and by Gnansounou et al. in 2009 (Edwards et al., 2007; Gnansounou et al., 2009; Johnson and Heinen, 2008). More seldom such studies include comparisons of effects on e.g. ecosystem quality, employment and economy. Dominguez-Faus et al., for example, point out that the effect on water security is seldom included and suggest the use of WF in the evaluation of biofuels (Dominguez-Faus et al., 2009).

The EF was used to assess different biofuels in a study reported by Stoeglehner and Narodoslawsky in 2009 (Stoeglehner and Narodoslawsky, 2009). The study concludes that EF analyses can be used to identify trends in land use demand for different scenarios. This information can then be used as a basis for further discussion about dedicating land to biofuels and other products.

It has been shown by the International Institute for Applied Systems Analysis, on behalf of the OPEC Fund for International Development, that national policies that strive towards increasing agrofuel production capacity can conflict with goals regarding food security (OFID, 2008). The same study concludes that agrofuels only contribute to modest increases in agricultural value in developing countries and also create additional risks of deforestation and other threats to biodiversity. Others acknowledge that improvements are needed in policies and technology in order to meet global demands for both food and biofuel feedstocks (McNeely et al., 2009; Tilman et al., 2009). The same argumentation should be applicable to an increase in the overall use of biomaterials in society, which could be one of the results of turning to wood-based diapers.

\subsection{Diapers}

Earlier assessments of diapers are of particular interest for the WooDi project. Life cycle environmental impacts of different types of diapers have been investigated in several studies (Aumonier and Collins, 2005; Edana, 2008; Hakala et al., 1997; Immink, 1999; Svensson, 1994; Wijkmark, 2004), but no studies have been found with the specific goal of 
comparing the use of materials with different resource bases in the diapers. The studies compare different brands and types of disposable and reusable diapers and have different scopes. In none of the studies is one alternative clearly superior or inferior to the others in terms of their environmental performance. The life cycle stages that give the largest impacts differ between different diaper types.

In an LCA study of disposable diapers, home laundered flat cloth diapers and commercially laundered prefolded cloth diapers delivered to the home, commissioned by the UK Environmental Agency in 2009 non-renewable resource depletion, acidification and climate impacts were the most significant categories when normalised to total European impacts (Aumonier and Collins, 2005). The assessment also considered ozone depletion, photo-oxidant formation, eutrophication, human toxicity and aquatic and terrestrial toxicity, but did not include impacts such as land use and impacts on biodiversity by each system. Impacts from waste management did not contribute substantially to the overall totals for any of the systems, although the proportion contributed by waste management not surprisingly is greater for the disposable diaper system than for the two reusable diaper systems. The results suggest that the focus for improving the environmental performance of disposable diapers should be on improvements in materials manufacturing and weight reduction and for reusable diapers, on reducing energy consumed during washing and drying. For the WooDi project, this suggests that apart from changing to a renewable material base, it is important to achieve a resource efficient material production stage as well as ensure that material function is not deteriorated to avoid the need for more material.

\section{Overview of results and future outlook}

That a material is "bio-based" is sometimes seen as a sustainability attribute in itself, but in a world with increasing competition for biomass resources, "bio-based" will not be enough. To include the scope of considerations that a holistic sustainability perspective requires, assessment parameters for many different areas should be used. However, in order to make the work load manageable, a selection that reflects the most important sustainability considerations for a specific case has to be made. The selection of assessment parameters and the weighting factors applied in later stages of the assessment should reflect the potential significant influence on sustainable development of the specific product systems at hand. In literature, a number of aspects to be evaluated in a sustainability assessment are proposed, both regarding environmental, social and economic matters. In Table 2, ten example areas are listed for which different sustainability parameters have been suggested, together with examples of how these can be expressed. The areas in Table 2 were selected because they have a clear connection to the comparison that is in focus in this study between the use of petroleum and renewable wood as the material base for products. However, other aspects than those listed may prove to be relevant and Table 2 should be seen as an illustration of suggestions from available literature rather than a recommendation. 
Table 2. Ten different areas potentially important to include in a sustainability comparison between the use of petroleum- and wood-based materials in products. These areas have been suggested or used in different assessments in literature.

\begin{tabular}{|c|c|c|c|c|c|}
\hline \multicolumn{2}{|c|}{ Sustainability aspect } & \multirow{2}{*}{$\begin{array}{l}\text { Examples of } \\
\text { assessment } \\
\text { parameters for } \\
\text { the aspect } \\
\begin{array}{l}\text { Petroleum usage } \\
\left(\mathrm{m}^{3}\right)\end{array}\end{array}$} & \multirow{2}{*}{$\begin{array}{l}\text { Examples of } \\
\text { methods or } \\
\text { initiatives } \\
\text { that include } \\
\text { the aspect } \\
\text { LCA, Eco- } \\
\text { efficiency, } \\
\text { SEEbalance, } \\
\text { ToSIA }\end{array}$} & \multirow{2}{*}{$\begin{array}{l}\text { Examples of studies in literature } \\
\text { that present or suggest the } \\
\text { aspect, but do not use it } \\
\text { (Andersson et al., 1998; Aumonier } \\
\text { and Collins, 2005; Baumann and } \\
\text { Tillman, 2004; Edana, 2008; } \\
\text { Gnansounou et al., 2009; Hakala } \\
\text { et al., 1997; Helming et al., 2008; } \\
\text { Immink, 1999; Lindner et al., 2010; } \\
\text { Svensson, 1994; Tufvesson and } \\
\text { Börjesson, 2008; Walter and } \\
\text { Stützel, 2009, 2009b; Wijkmark, } \\
\text { 2004) }\end{array}$} & \multirow{2}{*}{$\begin{array}{l}\text { Examples of } \\
\text { product } \\
\text { assessments in } \\
\text { literature that use } \\
\text { this aspect } \\
\text { (Andersson et al., } \\
\text { 1998; Aumonier } \\
\text { and Collins, 2005; } \\
\text { Gnansounou et } \\
\text { al., 2009; Hakala } \\
\text { et al., 1997; } \\
\text { Immink, 1999; } \\
\text { Svensson, 1994; } \\
\text { Tufvesson and } \\
\text { Börjesson, 2008) }\end{array}$} \\
\hline \multirow{5}{*}{ 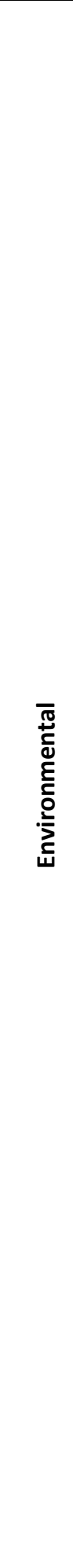 } & $\begin{array}{l}\text { Depletion of } \\
\text { non- } \\
\text { renewable } \\
\text { petroleum } \\
\text { resources* }\end{array}$ & & & & \\
\hline & $\begin{array}{l}\text { Occupation of } \\
\text { land area }\end{array}$ & $\begin{array}{l}\text { Land area usage } \\
\text { (hectare) }\end{array}$ & $\begin{array}{l}\text { Ecological } \\
\text { footprint, } \\
\text { LCA, Eco- } \\
\text { efficiency, } \\
\text { SEEbalance }\end{array}$ & $\begin{array}{l}\text { (Banse et al., 2008; Baumann and } \\
\text { Tillman, 2004; Berndes et al., } \\
\text { 2003; Gaia Foundation et al., } \\
\text { 2008; Graymore et al., 2008; } \\
\text { Helming et al., 2008; Holmberg et } \\
\text { al., 1999; Mathews, 2007; Nguyen } \\
\text { and Yamamoto, 2007; OFID, 2008; } \\
\text { Rathmann et al., 2010; } \\
\text { Stoeglehner and Narodoslawsky, } \\
\text { 2009; Wackernagel and Yount, } \\
\text { 1998, 2000; Walter and Stützel, } \\
\text { 2009, 2009b) }\end{array}$ & $\begin{array}{l}\text { (Nguyen and } \\
\text { Yamamoto, 2007; } \\
\text { Stoeglehner and } \\
\text { Narodoslawsky, } \\
\text { 2009) }\end{array}$ \\
\hline & $\begin{array}{l}\text { Emissions to } \\
\text { air of } \\
\text { greenhouse } \\
\text { gases }\end{array}$ & $\begin{array}{l}\text { Global warming } \\
\text { potential }\left(\mathrm{kg} \mathrm{CO}_{2}\right. \\
\text { eq.) }\end{array}$ & $\begin{array}{l}\text { LCA, Carbon } \\
\text { footprint, } \\
\text { ToSIA, Eco- } \\
\text { efficiency, } \\
\text { SEEbalance }\end{array}$ & $\begin{array}{l}\text { (Aumonier and Collins, 2005; } \\
\text { Baumann and Tillman, 2004; } \\
\text { Fehrenbach et al., 2008; } \\
\text { Gnansounou et al., 2008a; } \\
\text { Gnansounou et al., 2009; Helming } \\
\text { et al., 2008; Johnson and Heinen, } \\
\text { 2008; PAS 2050, 2008; RSB, 2008; } \\
\text { Walter and Stützel, 2009, 2009b) }\end{array}$ & $\begin{array}{l}\text { (Aumonier and } \\
\text { Collins, 2005; } \\
\text { Gnansounou et } \\
\text { al., 2008a; } \\
\text { Gnansounou et } \\
\text { al., 2009; Johnson } \\
\text { and Heinen, 2008) }\end{array}$ \\
\hline & $\begin{array}{l}\text { Emissions to } \\
\text { air (other } \\
\text { than } \\
\text { greenhouse } \\
\text { gases), water } \\
\text { and soil }\end{array}$ & $\begin{array}{l}\text { Acidification } \\
\text { potential }(\mathrm{kg} \mathrm{SO} \\
\text { eq.), } \\
\text { Photochemical } \\
\text { ozone creation } \\
\text { potential (kg } \\
\text { ethene eq.), } \\
\text { Eutrophication } \\
\text { potential (kg } \\
\mathrm{PO}_{4}{ }^{3-} \text { eq.) } \\
\end{array}$ & $\begin{array}{l}\text { LCA, RSB**, } \\
\text { ToSIA, Eco- } \\
\text { efficiency, } \\
\text { SEEbalance }\end{array}$ & $\begin{array}{l}\text { (Baumann and Tillman, 2004; } \\
\text { Helming et al., 2008; RSB, 2008; } \\
\text { Walter and Stützel, 2009, 2009b) }\end{array}$ & $\begin{array}{l}\text { (Mattsson et al., } \\
2000)\end{array}$ \\
\hline & $\begin{array}{l}\text { Impact on } \\
\text { biodiversity }\end{array}$ & $\begin{array}{l}\text { Number of } \\
\text { species per } \mathrm{m}^{2}, \\
\text { Population of } \\
\text { each species per } \\
\mathrm{m}^{2} \text {. }\end{array}$ & $\begin{array}{l}\text { Forest } \\
\text { certifications, } \\
\text { RSB**, some } \\
\text { specific LCAs, } \\
\text { ToSIA }\end{array}$ & $\begin{array}{l}\text { (Aumonier and Collins, 2005; } \\
\text { Baumann and Tillman, 2004; } \\
\text { Berndes et al., 2003; EBI, 2003; } \\
\text { Fehrenbach et al., 2008; Garraín et } \\
\text { al., 2007; Helming et al., 2008; } \\
\text { MEA, 2005; OFID, 2008; RSB, } \\
\text { 2008) }\end{array}$ & $\begin{array}{l}\text { (Mattsson et al., } \\
\text { 2000) }\end{array}$ \\
\hline
\end{tabular}


Accepted manuscript

\begin{tabular}{|c|c|c|c|c|c|}
\hline \multicolumn{2}{|c|}{ Sustainability aspect } & $\begin{array}{l}\text { Examples of } \\
\text { assessment } \\
\text { parameters for } \\
\text { the aspect }\end{array}$ & $\begin{array}{l}\text { Examples of } \\
\text { methods or } \\
\text { initiatives } \\
\text { that include } \\
\text { the aspect }\end{array}$ & $\begin{array}{l}\text { Examples of studies in literature } \\
\text { that present or suggest the } \\
\text { aspect, but do not use it }\end{array}$ & $\begin{array}{l}\text { Examples of } \\
\text { product } \\
\text { assessments in } \\
\text { literature that use } \\
\text { this aspect }\end{array}$ \\
\hline \multirow[b]{2}{*}{ :ִ } & $\begin{array}{l}\text { Operating } \\
\text { costs }\end{array}$ & $\begin{array}{l}\text { Cost of raw } \\
\text { material, Cost of } \\
\text { energy, Cost of } \\
\text { labour }\end{array}$ & $\begin{array}{l}\text { LCC, ToSIA, } \\
\text { SEEbalance, } \\
\text { Eco-efficency }\end{array}$ & $\begin{array}{l}\text { (Forest Stewardship Council, 1996; } \\
\text { Lindner et al., 2010; PEFC, 2010; } \\
\text { Saling et al., 2002; SFM, 2009) }\end{array}$ & Not found \\
\hline & Assets needed & $\begin{array}{l}\text { Capital } \\
\text { investment, } \\
\text { Investment in } \\
\text { research, } \\
\text { development, } \\
\text { increased } \\
\text { capacity and use } \\
\text { of new and } \\
\text { improved } \\
\text { technologies }\end{array}$ & $\begin{array}{l}\text { LCC, ToSIA, } \\
\text { SEEbalance, } \\
\text { Eco-efficency }\end{array}$ & (Schmidt et al., 2004; SFM, 2009) & Not found \\
\hline \multirow{3}{*}{$\overline{\frac{\pi}{u}}$} & $\begin{array}{l}\text { Impacts on } \\
\text { health or } \\
\text { safety }\end{array}$ & $\begin{array}{l}\text { Number of sick } \\
\text { days, Number of } \\
\text { severe accidents }\end{array}$ & $\begin{array}{l}\text { ISO 9001, Eco- } \\
\text { efficiency, } \\
\text { Social LCA, } \\
\text { SEEbalance, } \\
\text { ToSIA }\end{array}$ & $\begin{array}{l}\text { (Hunkeler, 2006; Walter and } \\
\text { Stützel, 2009, 2009b) }\end{array}$ & Not found \\
\hline & $\begin{array}{l}\text { Impacts on } \\
\text { surrounding } \\
\text { communities, } \\
\text { culture and } \\
\text { recreation }\end{array}$ & $\begin{array}{l}\text { Respect for } \\
\text { existing water } \\
\text { rights, } \\
\text { Opportunities for } \\
\text { employment, } \\
\text { training and } \\
\text { other services, } \\
\text { Participation of } \\
\text { women, Poverty } \\
\text { alleviation in } \\
\text { specific regions } \\
\end{array}$ & $\begin{array}{l}\text { Forest } \\
\text { certifications, } \\
\text { RSB**, } \\
\text { SEEbalance }\end{array}$ & $\begin{array}{l}\text { (Baumann and Tillman, 2004; } \\
\text { Fehrenbach et al., 2008; } \\
\text { Forest Stewardship Council, 1996; } \\
\text { Gaia Foundation et al., 2008; OFID, } \\
\text { 2008; RSB, 2008; Steen, 1999; } \\
\text { Walter and Stützel, 2009, 2009b) }\end{array}$ & Not found \\
\hline & $\begin{array}{l}\text { Adherence to } \\
\text { social rights }\end{array}$ & $\begin{array}{l}\text { Equal } \\
\text { remuneration for } \\
\text { work of equal } \\
\text { value, Protection } \\
\text { of the right to } \\
\text { organise }\end{array}$ & $\begin{array}{l}\text { Forest } \\
\text { certifications, } \\
\text { RSB**, Social } \\
\text { LCA, } \\
\text { SEEbalance }\end{array}$ & $\begin{array}{l}\text { (Fehrenbach et al., 2008; } \\
\text { Forest Stewardship Council, 1996; } \\
\text { Hunkeler, 2006; RSB, 2008) }\end{array}$ & Not found \\
\hline
\end{tabular}

* could alternatively be seen as an economic or even a social aspect

** RSB - Roundtable on Sustainable Biofuels

Table 2 also shows that while a lot of sustainability assessment parameters are discussed in literature, only a few, predominantly environmentally related ones, have so far been in actual use in case studies. One important reason for the present lack of assessment parameters is the difficulty in formulating assessable indicators that describe social interactions and impacts on ecosystem services such as biodiversity.

There is a need for methods that can assess and compare the depletion of petroleum resources and limitations in terms of land area, and other aspects that relate to the 
management of land, within the same comprehensive framework. Assessment parameters that describe these and other resource limitations are needed.

A sustainability assessment has to be based on a case-specific interpretation of important sustainability considerations and this has to be translated into a set of assessment parameters. Parameters then have to be assessed and aggregated into a holistic understanding of the sustainability performance, with opportunities to compare the sustainability profile of different products, also when the sustainability profiles peak in completely different areas. In the WooDi project, there is thus a need for a description of what is meant by sustainability, and a comprehensive set of parameters that cover the most important sustainability considerations. Many different sources of knowledge will have to be consulted, such as literature and different stakeholders in the value chain. Furthermore, a somewhat iterative approach is needed since some assessment parameters will have to be assessed in a preliminary screening before their potential relative importance can be understood.

Table 3 contains a summary of elements, found in different methods described in literature, which can be of use in the product sustainability assessment throughout the material development process in the WooDi project. The analytical approaches for assessing and comparing product sustainability are often not intended to cover the full range of potentially important sustainability aspects; they typically focus on selected aspects, e.g. on the CF (GHG emissions) of products and activities. The procedural approaches commonly contain targets or criteria that represent an acceptable level or outcome for each parameter. Most certification systems, e.g. FSC certification, only consider the management of the resources but do not consider the use of the product and how it is produced and therefore do not have a life cycle perspective. However, requirements within such systems often include a broad set of sustainability aspects.

Table 3. Overview of how elements of different methods can be of use in the sustainability assessment in the WooDi project

\begin{tabular}{|l|l|l|l|}
\hline Method/approach/system & $\begin{array}{l}\text { Description/Impact } \\
\text { considered }\end{array}$ & To keep in mind & Usefulness for WooDi project \\
\hline $\begin{array}{l}\text { Life Cycle Assessment (LCA) } \\
\text { in general }\end{array}$ & $\begin{array}{l}\text { Environmental impacts } \\
\text { over the entire life cycle }\end{array}$ & $\begin{array}{l}\bullet \text { Only environmental } \\
\text { performance } \\
\text { Different weighting } \\
\text { methods emphasise } \\
\text { different concerns } \\
\text { Different LCA studies } \\
\text { are not comparable } \\
\text { due to different goal } \\
\text { and scope }\end{array}$ & $\begin{array}{l}\text { - LCA methodology can be } \\
\text { useful in the sustainability } \\
\text { assessment } \\
\text { Common impact categories } \\
\text { can be used as a basis for } \\
\text { selection of case relevant } \\
\text { environmental assessment } \\
\text { parameters } \\
\text { Case studies provide } \\
\text { understanding of dominant } \\
\text { parameters and activities }\end{array}$ \\
\hline Carbon Footprint (CF) & $\begin{array}{l}\text { GHG emissions (climate } \\
\text { change) over the entire } \\
\text { life cycle }\end{array}$ & included & $\begin{array}{l}\text { As one of the sustainability } \\
\text { aspects in a sustainability } \\
\text { assessment }\end{array}$ \\
\hline
\end{tabular}




\begin{tabular}{|c|c|c|c|}
\hline Method/approach/system & $\begin{array}{l}\text { Description/Impact } \\
\text { considered }\end{array}$ & To keep in mind & Usefulness for WooDi project \\
\hline Water Footprint (WF) & $\begin{array}{l}\text { Fresh water used, } \\
\text { directly or indirectly, to } \\
\text { produce a product } \\
\text { (scope is generally } \\
\text { cradle-to-gate) }\end{array}$ & $\begin{array}{l}\text { - Water in the product's } \\
\text { use stage is generally } \\
\text { not included in the WF } \\
\text { of the product, but in } \\
\text { the WF of the } \\
\text { consumer using the } \\
\text { product }\end{array}$ & $\begin{array}{l}\text { - As one of the sustainability } \\
\text { aspects in a sustainability } \\
\text { assessment }\end{array}$ \\
\hline $\begin{array}{l}\text { Material Input Per Service } \\
\text { unit (MIPS) }\end{array}$ & $\begin{array}{l}\text { Amount of resource } \\
\text { input (resource } \\
\text { consumption) over the } \\
\text { entire life cycle }\end{array}$ & $\begin{array}{l}\text { - Unspecific to } \\
\text { particular materials as } \\
\text { well as substance } \\
\text { specific hazards }\end{array}$ & $\begin{array}{l}\text { - As a rough estimate of } \\
\text { resource use } \\
\text { - As one of the assessment } \\
\text { parameters in a } \\
\text { sustainability assessment }\end{array}$ \\
\hline Ecological Footprint (EF) & $\begin{array}{l}\text { Estimate of land area, } \\
\text { directly and indirectly, } \\
\text { over the entire life cycle }\end{array}$ & $\begin{array}{l}\text { - At present, methods } \\
\text { for translating } \\
\text { consumption of non- } \\
\text { renewable resources } \\
\text { into EF are lacking }\end{array}$ & $\begin{array}{l}\text { - As an initial screening } \\
\text { - As one of the assessment } \\
\text { parameters in a } \\
\text { sustainability assessment }\end{array}$ \\
\hline Life Cycle Costing (LCC) & $\begin{array}{l}\text { Internal and external } \\
\text { costs over the entire life } \\
\text { cycle }\end{array}$ & $\begin{array}{l}\text { - As most often used, } \\
\text { LCC only includes a } \\
\text { very limited type of } \\
\text { future costs and rarely } \\
\text { external costs. For a } \\
\text { sustainability } \\
\text { assessment, more } \\
\text { complete types of LCC } \\
\text { should be employed }\end{array}$ & $\begin{array}{l}\text { - To estimate investments } \\
\text { needed for alternative } \\
\text { solutions to material } \\
\text { development } \\
\text { - As one of the sustainability } \\
\text { aspects in a sustainability } \\
\text { assessment }\end{array}$ \\
\hline Social LCA & $\begin{array}{l}\text { Social impacts over the } \\
\text { entire life cycle }\end{array}$ & $\begin{array}{l}\text { - The scope varies from } \\
\text { impacts on workers } \\
\text { only to broader } \\
\text { societal consequences } \\
\text { like support to } \\
\text { developing countries }\end{array}$ & $\begin{array}{l}\text { - To give awareness of what } \\
\text { social impacts that may arise } \\
\text { during the whole } \\
\text { development process so that } \\
\text { development can be guided, } \\
\text { however, in early product } \\
\text { development, when many } \\
\text { features of the product } \\
\text { system are unknown, a focus } \\
\text { on the use and production } \\
\text { stages is suitable }\end{array}$ \\
\hline SEEbalance & $\begin{array}{l}\text { Comparing } \\
\text { sustainability of } \\
\text { products and processes } \\
\text { over the entire life cycle }\end{array}$ & $\begin{array}{l}\text { - Assesses, as presently } \\
\text { set up, the relative } \\
\text { impacts, comparing } \\
\text { two or several } \\
\text { product alternatives } \\
\text { and therefore } \\
\text { provides only limited } \\
\text { input on potential } \\
\text { improvements }\end{array}$ & $\begin{array}{l}\text { - As inspiration when defining } \\
\text { case relevant social, } \\
\text { environmental and } \\
\text { economic parameters } \\
\text { - For comparing the } \\
\text { sustainability of the } \\
\text { products in the final } \\
\text { assessment; requires that } \\
\text { the parameters and the } \\
\text { weighting method have } \\
\text { been adapted to the case }\end{array}$ \\
\hline $\begin{array}{l}\text { ToSIA - A Tool for } \\
\text { Sustainability Impact } \\
\text { Assessment of Forestry- } \\
\text { Wood Chains }\end{array}$ & $\begin{array}{l}\text { Sustainability } \\
\text { assessment software, } \\
\text { developed for European } \\
\text { forestry wood chains }\end{array}$ & $\begin{array}{l}\text { - Case-relevant } \\
\text { sustainability } \\
\text { parameters for the } \\
\text { diapers need to be } \\
\text { defined and if } \\
\text { necessary introduced }\end{array}$ & $\begin{array}{l}\text { - As inspiration when defining } \\
\text { case relevant parameters for } \\
\text { the forestry wood chain } \\
\text { - As a software tool for } \\
\text { managing the WooDi }\end{array}$ \\
\hline
\end{tabular}


Accepted manuscript

\begin{tabular}{|c|c|c|c|}
\hline Method/approach/system & $\begin{array}{l}\text { Description/Impact } \\
\text { considered }\end{array}$ & To keep in mind & Usefulness for WooDi project \\
\hline & & into the system & sustainability assessment \\
\hline Forest certifications & $\begin{array}{l}\text { FSC and PEFC } \\
\text { certification are based } \\
\text { on compliance to } \\
\text { performance standards }\end{array}$ & $\begin{array}{l}\text { - Consider the } \\
\text { management of } \\
\text { resources but not the } \\
\text { use of the product } \\
\text { and how it is } \\
\text { produced, i.e. do not } \\
\text { have a life cycle } \\
\text { perspective }\end{array}$ & $\begin{array}{l}\text { - As a control parameter, e.g. } \\
\text { compliance with FSC } \\
\text { certification or not }\end{array}$ \\
\hline $\begin{array}{l}\text { Petroleum oil certifications } \\
\text { and standards }\end{array}$ & $\begin{array}{l}\text { Certifications and } \\
\text { standards for quality } \\
\text { management like ISO } \\
9001: 2000 \text { and CEN/TC } \\
12\end{array}$ & $\begin{array}{l}\text { Developed to aid in } \\
\text { compliance to laws } \\
\text { and to facilitate } \\
\text { exchange of } \\
\text { equipment, not for } \\
\text { moving towards } \\
\text { sustainability }\end{array}$ & $\begin{array}{l}\text { - As a control parameter, e.g. } \\
\text { for compliance with laws }\end{array}$ \\
\hline
\end{tabular}

The SEEbalance and ToSIA methods include environmental, economic and social parameters. Both include lists of parameters that might be useful in product assessments, however, none of the approaches advice in the selection of parameters to reflect important and relevant sustainability considerations for a specific case. In fact, the seemingly well thought-through lists may even trick analysts into thinking that a generic list is suitable for every system. Using the same parameter list facilitates comparison between different studies and may be relevant in some situations. For the WooDi project, however, the development of the new material is to be guided towards a more sustainable diaper product and such a process must be informed using a parameter set that reflects the specific definition of what a sustainable product implies in the specific case.

In the SEEbalance scheme, the weighting is intended to be performed by experts and the SEEbalance practitioner while the ToSIA scheme stresses and encourages the involvement of different stakeholders in the weighting procedure. In the built-in MCA tool, different stakeholders can propose a weighting factor to each indicator, to rank alternatives. The range of results of the different weighting proposals is also visualised to the stakeholders. ToSIA results will probably be more understandable to people that have been included in the process and can thereby provide better guidance to these people in their work. The result of the sustainability comparison in SEEbalance, the SEEcube, is intended for decisionmakers that have not been involved in the process and is designed to be easy to grasp but not to provide any details on the background or limitations of the results. The method is not constructed with the aim to guide project team members throughout a product development process.

It is clear that available methods contain many useful elements and approaches, as can be seen in Table 3. For the needs of the WooDi project there are two important gaps: there is a lack of parameters describing potentially important sustainability considerations in a comparison of the use of wood or petroleum as raw material and there is a need for an 
approach that establishes case relevant sustainability assessment parameter sets. To fill the gaps noted in this screening of methods, an approach for establishing case relevant product sustainability assessment parameter sets should be developed.

\section{Conclusions}

This review was performed based on the need of a method for selecting and assessing a set of parameters for comparing the sustainability of incontinence diapers produced with either petroleum-based or wood-based materials. The review was made based on the presumption that such a set of assessment parameters, as well as their relative weights, must be developed based on the circumstances of the specific case.

The review revealed that a diverse number of approaches and methods exist that can assess different attributes or articulations of product sustainability for parts of or whole product life cycles. Numerous sustainability assessment parameters, mainly for environmental aspects, have been used or suggested. Almost all reviewed assessment approaches use premade lists of assessment parameters but without advice on how to adjust them towards a more case-relevant set of parameters.

Parameters are lacking in some areas, and also knowledge of how to describe these missing parameters. This is, for example, the case for social progress, and impacts on biodiversity and other ecosystem services.

In moving towards a bio-based society, comparisons between use of different types of resources faced with different types of restrictions will be increasingly important. In available literature, no ready-to-use methods for comparing use of different types of limited resources, like petroleum, land area and water (as in a comparison between petroleumbased and wood-based materials), have been found.

Finally, approaches are lacking for establishing case specific weighting of parameters, which is necessary for handling case specific trade-offs.

\section{Acknowledgements}

This research would not have been possible without financial and in-kind support from Vinnova, SCA Hygiene Products AB, Södra Cell AB and Chalmers University of Technology.

\section{References}

Andersson, K., Eide, M.H., Lundqvist, U., Mattsson, B., 1998. The feasibility of including sustainability in LCA for product development. Journal of Cleaner Production 6, 289-298.

Andrews, E.S., Barthel, L.-P., Beck, T., Benoît, C., Ciroth, A., Cucuzzella, C., Gensch, C.-O., Hébert, J., Lesage, P., Manhart, A., Mazeau, P., Mazijn, B., Methot, A.-L., Moberg, A., KTH, Norris, G., Parent, J., Prakash, S., Reveret, J.-P., Spillemaeckers, S., Ugaya, C.M.L., Valdivia, S., Weidema, B., 2009. Guidelines for Social Life Cycle Assessment of Products, in: Benoît, C., Mazijn, B. (Eds.). United Nations Environment Programme UNEP. 


\section{Accepted manuscript}

Antón, A., Castells, F., Montero, J.I., 2007. Land use indicators in life cycle assessment. Case study: The environmental impact of Mediterranean greenhouses. Journal of Cleaner Production 15, 432-438.

ASTM, 2009. Standard Specification for Fuel in: ASTM International (Ed.), ASTM D396-09.

Aumonier, S., Collins, M., 2005. Life Cycle Assessment of Disposable and Reusable Nappies in the UK. Environment Agency.

Banse, M., Nowicki, P., Meijl, H.v., 2008. Why are current world food prices so high? LEI Wageningen UR, Wageningen, The Netherlands.

Baral, A., Bakshi, B.R., Smith, R.L., 2012. Assessing resource intensity and renewability of cellulosic ethanol technologies using Eco-LCA. Environmental Science and Technology 46, 2436-2444.

Baumann, H., Tillman, A.M., 2004. The Hitchhiker's Guide to LCA. An Orientation in Life Cycle Assessment Methodology and Application. Studentlitteratur, Lund.

Bengtsson, M., Steen, B., 2000. Weighting in LCA - approaches and applications. Environmental Progress 19, $101-109$.

Benoît, C., Norris, G.A., Valdivia, S., Ciroth, A., Moberg, A., Bos, U., Prakash, S., Ugaya, C., Beck, T., The guidelines for social life cycle assessment of products: just in time! International Journal of Life Cycle Assessment, 1-8.

Berg, S., Fischbach, J., Brüchert, F., Poissonnet, M., Pizzirani, S., Varet, A., Sauter, U.H., 2012. Towards assessing the sustainability of European logging operations. European Journal of Forest Research 131, 81-94.

Berndes, G., Hoogwijk, M., van den Broek, R., 2003. The contribution of biomass in the future global energy supply. Biomass \& Energy 25.

Bringezu, S., Schutz, H., O’Brien, M., Kauppi, L., Howarth, R.W., McNeely, J., 2009a. Towards sustainable production and use of resources: Assessing Biofuels. United Nations Environmental Programe (UNEP).

Bringezu, S., Schütz, H., Arnold, K., Merten, F., Kabasci, S., Borelbach, P., Michels, C., Reinhardt, G.A., Rettenmaier, N., 2009b. Global implications of biomass and biofuel use in Germany - Recent trends and future scenarios for domestic and foreign agricultural land use and resulting GHG emissions. Journal of Cleaner Production 17, S57-S68.

Buchholz, T., Luzadis, V.A., Volk, T.A., 2009. Sustainability criteria for bioenergy systems: results from an expert survey. Journal of Cleaner Production 17, S86-S98.

Börjesson, P., Tufvesson, L.M., 2011. Agricultural crop-based biofuels - Resource efficiency and environmental performance including direct land use changes. Journal of Cleaner Production 19, 108-120.

CHAINET, 2002. Analytical Tools for Environmental Design and Management in a Systems Perspective. Kluwer Academic Publisher, Dordrecht, the Netherlands.

Chesneau, J.B., Le Net, E., Berg, S., 2012. A transport tool to evaluate sustainability impacts of transport processes within the Forest Wood Chain. European Journal of Forest Research 131, 73-80.

Ciroth, A., Finkbeiner, M., Hildenbrand, J., Klöpffer, W., Mazijn, B., Prakash, S., Sonnemann, G., Traverso, M., Ugaya, C.M.L., Valdivia, S., Vickery-Niederman, G., 2011. Towards a Life Cycle Sustainability Assessment: Making informed choices on products, in: Valdivia, S., Ugaya , C.M.L., Sonnemann, G., Hildenbrand, J. (Eds.). UNEP/SETAC Life Cycle Initiative.

Cornelissen, S., Dehue, B., 2009. Summary of approaches to accounting for indirectr impacts of biofuel production, Ecofys as Commissioned by Roundtable on Sustainable Biofuels, Utrecht.

Dominguez-Faus, R., Powers, S.E., Burken, J.G., Alvarez, P.J., 2009. The water footprint of biofuels: A drink or drive issue? Environmental Science and Technology 43, 3005-3010.

Dyllick, T., Hockerts, K., 2002. Beyond the business case for corporate sustainability. Business Strategy and the Environment 11, 130-141.

Earles, J.M., Halog, A., 2011. Consequential life cycle assessment: A review. International Journal of Life Cycle Assessment 16, 445-453.

EBI, 2003. Integrating Biodiversity Conservation into Oil \& Gas Development, in: initiative, T.e.b. (Ed.).

Edana, 2008. Sustainability Report: Absorbent Hygiene Products 2007-2008, in: Comittee, T.A.H.P. (Ed.). Edana.

Edwards, R., Larivé, J.-F., Mahieu, V., Rouveirolles, P., 2007. Well-to-Wheels analysis of future automotive fuels and powertrains in the European context. EUCAR (the European Council for Automotive R\&D), CONCAWE (the oil 


\section{Accepted manuscript}

companies' European association for environment, health and safety in refining and distribution) and JRC/IES (the Institute for Environment and Sustainability of the EU Commission's Joint Research Centre).

Eforwood, 2009. Sustainability Impact Assessment of the Forest-Wood Chain.

European Commission, 2009a. ILCD Handbook: Analysis of existing Environmental Impact Assessment methodologies for use in Life Cycle Assessment (LCA) - (Background document), in: System, I.R.L.C.D. (Ed.).

European Commission, 2009b. Renewable energy, EU directive 2009/28/EC Article 19. .

Farrell, A.E., Plevin, R.J., Turner, B.T., Jones, A.D., O'Hare, M., Kammen, D.M., 2006. Ethanol can contribute to energy and environmental goals. Science 311, 506-508.

Fehrenbach, H., Giegrich, J., Reinhardt, G., Schmitz, J., Sayer, U., Gretz, M., Seizinger, E., Lanje, K., 2008. Criteria for a Sustainable Use of bioenergy on a Global Scale, in: Institute für Energie- und Umweltforschung, F.A.D., Germanwatch (Ed.).

Finnveden, G., 1997. Valuation methods within LCA - Where are the values? International Journal of Life Cycle Assessment 2, 163-169.

Finnveden, G., 1999. A Critical Review of Operational Valuation/Weighting Methods for Life Cycle Assessment, in: AFN (Ed.), AFR-report. Swedish Environmental Protection Agency, Stockholm, Sweden.

Finnveden, G., Hauschild, M.Z., Ekvall, T., Guinée, J., Heijungs, R., Hellweg, S., Koehler, A., Pennington, D., Suh, S., 2009. Recent developments in Life Cycle Assessment. Journal of Environmental Management 91, 1-21.

Finnveden, G., Moberg, A., 2005. Environmental systems analysis tools - An overview. Journal of Cleaner Production 13, 1165-1173.

Foley, J.A., DeFries, R., Asner, G.P., Barford, C., Bonan, G., Carpenter, S.R., Chapin, F.S., Coe, M.T., Daily, G.C., Gibbs, H.K., Helkowski, J.H., Holloway, T., Howard, E.A., Kucharik, C.J., Monfreda, C., Patz, J.A., Prentice, I.C., Ramankutty, N., Snyder, P.K., 2005. Global consequences of land use. Science 309, 570-574.

Forest Stewardship Council, 1996. FSC Principles and criteria for forest stewardship in: Council, F.S. (Ed.), FSC-STD01-001 (version 4-0) EN.

Fritsche, U.R., Sims, R.E.H., Monti, A., 2010. Direct and indirect land-use competition issues for energy crops and their sustainable production - an overview. Biofuels, Bioproducts and Biorefining 4, 692-704.

Gaia Foundation, Biofuelwatch, The African Biodiversity network, Salva la Selva, Watch Indonesia, EcoNexus, 2008. Agrofuels and the myth of the marginal lands in: A briefing by Gaia Foundation, B., The African Biodiversity network, Salva la Selva, Watch Indonesia, EcoNexus. (Ed.).

Garraín, D., Vidal, R., Franco, V., 2007. Land use in LCA of biomaterials. Proceedings of the 3rd International Conference on Life Cycle Management.

Gnansounou, E., Dauriat, A., Panichelli, L., Villegas, J., 2008a. Energy and greenhouse gas balances of biofuels: Biases induced by LCA modelling choices. Journal of Scientific and Industrial Research 67, 885-897.

Gnansounou, E., Dauriat, A., Villegas, J., Panichelli, L., 2009. Life cycle assessment of biofuels: Energy and greenhouse gas balances. Bioresource Technology 100, 4919-4930.

Gnansounou, E., Panichelli, L., Dauriat, A., Villegas, J.D., 2008b. Accounting for indirect land-use changes in GHG balances of biofuels - Review of current approaches, ENAC - Faculté Environnement naturel architectural et construit, ICARE - Institut des infrastructures, des ressources et de l'environnement and LASEN - Laboratoire de systèmes énergétiques.

Graymore, M.L.M., Sipe, N.G., Rickson, R.E., 2008. Regional sustainability: How useful are current tools of sustainability assessment at the regional scale? Ecological Economics 67, 362-372.

Hakala, S., Virtanen, Y., Meinander, K., Tanner, T., 1997. Life-cycle assessment, comparison of biopolymer and traditional diaper systems. VTT Chemical Technology and Neste Corporation, p. $91+$ app.

Helming, K., Pérez-Soba, M., Tabbush, P., 2008. Sustainability Impact Assessment of Land Use Changes. SpringerVerlag, Berlin Heidelberg.

Hoekstra, A., Chapagain, A., Aldaya, M., Mekonnen, M., 2009. Water Footprint Manaul State of the Art. Water Footprint Network, Enschede.

Holmberg, J., Lundqvist, U., Robért, K.H., Wackernagel, M., 1999. The ecological footprint from a systems perspective of sustainability. International Journal of Sustainable Development and World Ecology 6, 17-33. 


\section{Accepted manuscript}

Hunkeler, D., 2006. Societal LCA methodology and case study. International Journal of Life Cycle Assessment 11, 371382.

Höjer, M., Ahlroth, S., Dreborg, K.H., Ekvall, T., Finnveden, G., Hjelm, O., Hochschorner, E., Nilsson, M., Palm, V., 2008. Scenarios in selected tools for environmental systems analysis. Journal of Cleaner Production 16, 1958-1970.

Immink, H., 1999. Polymer produced from biomass: Is it Sustainable? Based on the life cycle of the diaper system, Department of Technical Environmental Planning. Chalmers University of Technology, Göteborg, p. 73.

IPCC, 2000. Land Use, Land-Use Change and Forestry, in: Watson, R.T., Noble, I.R., Bolin, B., Ravindranath, N.H., Verardo, D.J., Dokken, D.J. (Eds.), p. pp 375.

Johnson, E., Heinen, R., 2008. Carbon footprints of biofuels \& petrofuels. Industrial Biotechnology 4, 257-261.

Jørgensen, A., Le Bocq, A., Nazarkina, L., Hauschild, M., 2008. Methodologies for social life cycle assessment. International Journal of Life Cycle Assessment 13, 96-103.

Kloepffer, W., 2008. Life cycle sustainability assessment of products (with Comments by Helias A. Udo de Haes, p. 95). International Journal of Life Cycle Assessment 13, 89-94.

Korpi, E., Ala-Risku, T., 2008. Life cycle costing: A review of published case studies. Managerial Auditing Journal 23, 240-261.

Kounina, Margni, Koehler, Bayart, Boulay, Berger, Bulle, Frischknecht, Mila-i-Canals, Motoshita, Nunez, Peters, Pfister, Ridoutt, Van Zelm, Verones, Humbert, 201X. Review of methods addressing water in a life cycle perspective. Submitted to International Journal of Life Cycle Assessment.

Kölsch, D., Saling, P., Kicherer, A., Grosse-Sommer, A., Schmidt, I., 2008. How to measure social impacts? A socioeco-efficiency analysis by the SEEBALANCE ${ }^{\circledR}$ method. International Journal of Sustainable Development 11, 1-23.

Lindner, M., Suominen, T., Garcia, J., Palosuo, T., 2008. Deliverable D1.4.6 - Documentation of ToSIA developments up to month 23.

Lindner, M., Suominen, T., Palosuo, T., Garcia-Gonzalo, J., Verweij, P., Zudin, S., Päivinen, R., 2010. ToSIA-A tool for sustainability impact assessment of forest-wood-chains. Ecological Modelling 221, 2197-2205.

Lindner, M., Werhahn-Mees, W., Suominen, T., Vötter, D., Zudin, S., Pekkanen, M., Päivinen, R., Roubalova, M., Kneblik, P., Brüchert, F., Valinger, E., Guinard, L., Pizzirani, S., 2012. Conducting sustainability impact assessments of forestry-wood chains: Examples of ToSIA applications. European Journal of Forest Research 131, 21-34.

Mathews, J.A., 2007. Biofuels: What a Biopact between North and South could achieve. Energy Policy 35, 3550-3570.

Mattsson, B., Cederberg, C., Blix, L., 2000. Agricultural land use in life cycle assessment (LCA): Case studies of three vegetable oil crops. Journal of Cleaner Production 8, 283-292.

Mattsson, B., Cederberg, C., Ljung, M., 1998. Principles for environmental assessment of land use in agriculture, SIKreport. Institutet för livsmedel och bioteknik (SIK), Göteborg.

McNeely, J.A., Solh, M., Hiremath, R.B., Kumar, B., Suarez, P.A.Z., Uprety, K., Abdulrahim, M.A., Ruf, F., Legoupil, J.C., 2009. Experts address the question: "Can the growing demand for biofuels be met without threatening food security?". Natural Resources Forum 33, 171-173.

MEA, 2005. Ecosystems and human wellbeing. Biodiversity synthesis., in: Assessment, M.E. (Ed.), Washington.

Mendoza, G.A., Martins, H., 2006. Multi-criteria decision analysis in natural resource management: A critical review of methods and new modelling paradigms. Forest Ecology and Management 230, 1-22.

Michelsen, O., 2008. Assessment of land use impact on biodiversity: Proposal of a new methodology exemplified with forestry operations in Norway. International Journal of Life Cycle Assessment 13, 22-31.

Milà i Canals, L., Bauer, C., Depestele, J., Dubreuil, A., Knuchel, R.F., Gaillard, G., Michelsen, O., Mu?ller-Wenk, R., Rydgren, B., 2007. Key elements in a framework for land use impact assessment within LCA. International Journal of Life Cycle Assessment 12, 5-15.

Munthe, C., 1997. Etiska aspekter på jordbruk (Ethical aspects on agriculture), in: Agriculture), J.t.S.b.o. (Ed.).

Nguyen, H.X., Yamamoto, R., 2007. Modification of ecological footprint evaluation method to include non-renewable resource consumption using thermodynamic approach. Resources, Conservation and Recycling 51, 870-884.

OFID, 2008. Biofuels and Food Security. Implications of an accelerated biofuels production., in: IIASA, S.o.t.O.s.p.b. (Ed.), OFID Pamphlet Series 38 (2009) p. 42. 


\section{Accepted manuscript}

Panagopoulos, T., 2009. Linking forestry, sustainability and aesthetics. Ecological Economics 68, 2485-2489.

PAS 2050, 2008. Specification for the assessment of the life cycle greenhouse gas emissions of goods and services, in: Institution, B.S. (Ed.). British Standards Institution.

PEFC, 2010. The Programme for the Endorsement of Forest Certification (PEFC). PEFC International, Geneva.

Penman, T.D., Law, B.S., Ximenes, F., 2010. A proposal for accounting for biodiversity in life cycle assessment. Biodiversity and Conservation 19, 3245-3254.

Pennington, D.W., Potting, J., Finnveden, G., Lindeijer, E., Jolliet, O., Rydberg, T., Rebitzer, G., 2004. Life cycle assessment Part 2: Current impact assessment practice. Environment International 30, 721-739.

Rametsteiner, E., Simula, M., 2003. Forest certification - An instrument to promote sustainable forest management? Journal of Environmental Management 67, 87-98.

Rathmann, R., Szklo, A., Schaeffer, R., 2010. Land use competition for production of food and liquid biofuels: An analysis of the arguments in the current debate. Renewable Energy 35, 14-22.

Rebitzer, G., Ekvall, T., Frischknecht, R., Hunkeler, D., Norris, G., Rydberg, T., Schmidt, W.P., Suh, S., Weidema, B.P., Pennington, D.W., 2004. Life cycle assessment Part 1: Framework, goal and scope definition, inventory analysis, and applications. Environment International 30, 701-720.

Rebitzer, G., Hunkeler, D., 2003. Life cycle costing in LCM: Ambitions, opportunities, and limitations - Discussing a framework. International Journal of Life Cycle Assessment 8, 253-256.

Ritthoff, M., Rohn, H., Liedtke, C., 2002. Calculating MIPS resource productivity of products and services. Wuppertal Institute for Climate, Environment and Energy.

Robèrt, K.H., 2000. Tools and concepts for sustainable development, how do they relate to a general framework for sustainable development, and to each other? Journal of Cleaner Production 8, 243-254.

RSB, 2008. Global principles and criteria for sustainable biofuels production Version Zero, in: Biofuels, T.R.o.S. (Ed.). The Roundtable on Sustainable Biofuels.

Saling, P., Kicherer, A., Dittrich-KrÃammer, B., Wittlinger, R., Zombik, W., Schmidt, I., Schrott, W., Schmidt, S., 2002. Eco-efficiency analysis by BASF: The method. International Journal of Life Cycle Assessment 7, 203-218.

Saling, P., Maisch, R., Silvani, M., König, N., 2005. Assessing the environmental-hazard potential for life cycle assessment, eco-efficiency and SEEbalance ${ }^{\circledR}$. International Journal of Life Cycle Assessment 10, 364-371.

Schmidt, I., Meurer, M., Saling, P., Kicherer, A., Reuter, W., Gensch, C.O., 2004. SEEbalance ®: Managing sustainability of products and processes with the socio-eco-efficiency analysis by BASF. Greener Management International, 79-94.

Searchinger, T., Heimlich, R., Houghton, R.A., Dong, F., Elobeid, A., Fabiosa, J., Tokgoz, S., Hayes, D., Yu, T.H., 2008. Use of U.S. croplands for biofuels increases greenhouse gases through emissions from land-use change. Science 319, 1238-1240.

SFM, 2009. Sustainable forest management - indicator knowledge base. The University of British Columbia, Canada.

Smeets, E., Junginger, M., Faaij, A., Walter, A., Dolzan, P., 2006. Sustainability of Brazilian Bio-ethanol.

Steen, B., 1999. A systematic approach to environmental priority strategies in product development (EPS), version 2000 - Models and data from the default model. CPM Report.

Steen, B.A., 2006. Describing values in relation to choices in LCA. International Journal of Life Cycle Assessment 11, 277-283.

Stoeglehner, G., Narodoslawsky, M., 2009. How sustainable are biofuels? Answers and further questions arising from an ecological footprint perspective. Bioresource Technology 100, 3825-3830.

Swan, G., 1998. Evaluation of Land Use in Life Cycle Assessment, in: 1998:2, C.r. (Ed.), Göteborg.

Svensson, S., 1994. Miljökriterier för blöjor och liknande produkter. Projekt handla miljövänligt, Naturskyddsföreningen.

TEEB, 2009. TEEB-The Economics of Ecosystems \& Biodiversity for national and International Policy Makers -

Responding to the value of nature.

Tilman, D., Socolow, R., Foley, J.A., Hill, J., Larson, E., Lynd, L., Pacala, S., Reilly, J., Searchinger, T., Somerville, C., Williams, R., 2009. Beneficial biofuels - The food, energy, and environment trilemma. Science 325, $270-271$. 


\section{Accepted manuscript}

Tufvesson, L.M., Börjesson, P., 2008. Wax production from renewable feedstock using biocatalysts instead of fossil feedstock and conventional methods. International Journal of Life Cycle Assessment 13, 328-338.

U. R. Fritsche, K. J. Hennenberg, A. Hermann, K. Hünecke, Herrera, R., H. Fehrenbach, E. Roth, A. Hennecke, Giegrich, J., 2010. Development of strategies and sustainability standards for the certification of biomass for international trade. Öko-Institut, Büro Darmstadt and IFEU - Institut für Energie- und Umweltforschung Heidelberg.

Udo de Haes, H.A., Finnveden, G., Goedkoop, M., Hauschild, M., Hertwich, E.G., Hofsetter, P., Jolliet, O., Klöpffer, W., Krewitt, W., Lindeijer, E., Müller-Wenk, R., Olsen, S.I., Pennington, D.W., Potting, J., Steen, B., 2002. Life-cycle impact assessment: striving towards best practice, in: Green, A. (Ed.). SETAC press.

Wackernagel, M., Rees, W., 1996. Our Ecological Footprint: Reducing Human Impact on the Earth New Society Publishers,, Gabriolia Island, BC.

Wackernagel, M., Yount, J.D., 1998. The ecological footprint: An indicator of progress toward regional sustainability. Environmental Monitoring and Assessment 51, 511-529.

Wackernagel, M., Yount, J.D., 2000. Footprints for sustainability: The next steps. Environment, Development and Sustainability 2, 21-42.

Walter, C., Stützel, H., 2009. A new method for assessing the sustainability of land-use systems (I): Identifying the relevant issues. Ecological Economics 68, 1275-1287.

Walter, C., Stützel, H., 2009b. A new method for assessing the sustainability of land-use systems (II): Evaluating impact indicators. Ecological Economics 68, 1288-1300.

Water Footprint Network, 2009. Water Footprint. Water Footprint Network.

WCED, 1987. Our Common Future, in: World Comission on Environment and Development (Gro Harlem Brundtland, C. (Ed.), New York.

Wiedmann, T., Minx, J., 2007. A Definition of 'Carbon Footprint'. Centre for Integrated Sustainability Analysis, Durham, DH7 7FB, United Kingdom.

Wijkmark, J., 2004. Blöjor och miljö - en miljögranskning av sju olika sorters barnblöjor. VERNA Ekologi AB.

Vogtländer, J.G., Lindeijer, E., Witte, J.P.M., Hendriks, C., 2004. Characterizing the change of land-use based on flora: Application for EIA and LCA. Journal of Cleaner Production 12, 47-57.

Wolfslehner, B., Brüchert, F., Fischbach, J., Rammer, W., Becker, G., Lindner, M., Lexer, M.J., 2012. Exploratory multicriteria analysis in sustainability impact assessment of forest-wood chains: The example of a regional case study in Baden-Württemberg. European Journal of Forest Research 131, 47-56.

von Blottnitz, H., Curran, M.A., 2007. A review of assessments conducted on bio-ethanol as a transportation fuel from a net energy, greenhouse gas, and environmental life cycle perspective. Journal of Cleaner Production 15, 607-619.

Woodward, D.G., 1997. Life cycle costing - Theory, information acquisition and application. International Journal of Project Management 15, 335-344.

Wrisberg, N., Udo de Haes, H.A., Triebswetter, U., Eder, P., Clift, R., 2002. Analytical tools for environmental design and management in a systems perspective. Kluwer academic publishers, Dordrecht, The Netherlands.

Zamagni, A., Buttol, P., Buonamici, R., Masoni, P., Guinee, J.B., Huppes, G., Heijungs, R., van der Voet, E., Ekvall, T., Rydberg, T., 2009. D20 Blue paper on Life Cycle Sustainability Analysis. project CALCAS Co-ordination action for innovation in life-cycle analysis for sustainability.

Zamagni, A., Guinée, J., Heijungs, R., Masoni, P., Raggi, A., 2012. Lights and shadows in consequential LCA. International Journal of Life Cycle Assessment, 1-15.

Zhang, Y.I., Anil, B., Bakshi, B.R., 2010. Accounting for ecosystem services in life cycle assessment part II: Toward an ecologically based LCA. Environmental Science and Technology 44, 2624-2631. 